Article

\title{
Production Profile of Farms and Methane and Nitrous Oxide Emissions
}

\author{
Zofia Koloszko-Chomentowska ${ }^{1, * \mathbb{D}}$, Leszek Sieczko ${ }^{2}$ (D) and Roman Trochimczuk ${ }^{3}$ (D) \\ 1 Department of Management Economy and Finance, Bialystok University of Technology, \\ 15-351 Bialystok, Poland \\ 2 Department of Biometry, Warsaw University of Life Sciences-SGGW, 02-787 Warsaw, Poland; \\ leszek_sieczko@sggw.edu.pl \\ 3 Department of Automatic Control and Robotics, Bialystok University of Technology, 15-351 Białystok, Poland; \\ r.trochimczuk@pb.edu.pl \\ * Correspondence: z.koloszko@pb.edu.pl
}

Citation: Koloszko-Chomentowska,

Z.; Sieczko, L.; Trochimczuk, R.

Production Profile of Farms and

Methane and Nitrous Oxide

Emissions. Energies 2021, 14, 4904.

https://doi.org/10.3390/en14164904

Academic Editors: Vitaliy Krupin and Roman Podolets

Received: 15 April 2021

Accepted: 5 August 2021

Published: 11 August 2021

Publisher's Note: MDPI stays neutral with regard to jurisdictional claims in published maps and institutional affiliations.

Copyright: (c) 2021 by the authors. Licensee MDPI, Basel, Switzerland. This article is an open access article distributed under the terms and conditions of the Creative Commons Attribution (CC BY) license (https:/ / creativecommons.org/licenses/by/ $4.0 /)$.
Abstract: The negative impact of agricultural production on the environment is manifested, above all, in the emission of greenhouse gases (GHG). The goals of this study were to estimate methane and nitrous oxide emissions at the level of individual farms and indicate differences in emissions depending on the type of production, and to investigate dependencies between greenhouse gas emissions and economic indicators. Methane and nitrous oxide emissions were estimated at three types of farms in Poland, based on FADN data: field crops, milk, and mixed. Data were from 2004-2018. Statistical analysis confirmed the relationship between greenhouse gas emissions and economic performance. On milk farms, the value of methane and nitrous oxide emissions increased with increased net value added and farm income. Milk farms reached the highest land productivity and the highest level of income per 1 ha of farmland. On field crops farms, the relationship between net value added and farm income and methane and nitrous oxide emissions was negative. Animals remain a strong determinant of methane and nitrous oxide emissions, and the emissions at milk farms were the highest. On mixed farms, emissions result from intensive livestock and crop production. In farms of the field crops type, emissions were the lowest and mainly concerned crops.

Keywords: agricultural production; emission; methane; nitrous oxide; dairy cows; field crops; agricultural production; family farm income; land productivity

\section{Introduction}

The 2030 Agenda for Sustainable Development, adopted in 2015, is a comprehensive plan of development for the world established by the United Nations (UN). All UN member states committed to taking action toward creating adequate living conditions and conditions for economic progress while simultaneously protecting the environment and counteracting climate change. Climate change is progressing due to increased greenhouse gas (GHG) emissions, including carbon dioxide $\left(\mathrm{CO}_{2}\right)$. In 2020, annual $\mathrm{CO}_{2}$ emissions increased by $20 \%$ globally compared to 2005 [1]. East Asian and Pacific countries emitted more $\mathrm{CO}_{2}$ than in 2005 (by 50\%), whereas emissions decreased in North America (by 13\%) and in European and Central Asian countries (by 9\%) [1]. The amount of greenhouse gases emitted annually by the EU decreased by $12 \%$ compared to 2010, while Poland emits over 400 million tons of greenhouse gases annually, which makes up $9.8 \%$ of the EU's emissions [1]. It is necessary to take action over the next several years to reduce the risk of irreversible effects of climate change, particularly since the Earth will continue to react to increases in greenhouse gas emissions for a long time after they are reduced [2]. Increasing the use of renewable energy sources is one measure that can contribute to the reduction of greenhouse gas emissions. Poland is involved in actions aimed at limiting climate change that are being undertaken by the international community. It is one of the signatories of the UN Framework Convention on Climate Change (UNFCCC) since 1992 and the Kyoto Protocol since 2002 [3]. 
Agriculture is one of the sectors of the economy that has a strong relationship with the natural environment. The technological, biological, and organizational progress that is being made affords access to increasingly modern production technologies. This leads to improvements in the technical and economic efficiency of agricultural production. However, these changes are generating a series of threats to the natural environment. In relation to the growth of the global population and a growing demand for food, there is pressure to increase the magnitude of agricultural production. Today, technical capabilities with regard to increasing the scale of production are not a limitation, as this process is accompanied by economic benefits; however, an environmental barrier does arise. The negative impact of agricultural production on the environment is manifested, above all, in the emission of greenhouse gases (GHGs), mainly nitrous oxide $\left(\mathrm{N}_{2} \mathrm{O}\right)$ and methane $\left(\mathrm{CH}_{4}\right)$ [4-6].

The Kyoto Protocol lists $\mathrm{CO}_{2}$ as one of the gases that has an influence on the greenhouse effect. This is the most important factor in climate change, and is covered in most studies. However, some researchers are voicing the opinion that basing estimates solely on $\mathrm{CO}_{2}$ emissions and omitting other gases in the balance associated with agriculture, particularly in rural and urban-rural municipalities, leads to underestimation of GHG emissions from Polish agriculture [7-9]. Research by Wiśniewski [7] shows that over half of the total emissions from agriculture in Poland is associated with animal raising and breeding. This is confirmed by the results of many studies. GHG emissions from agriculture in Africa are showing some of the highest rates of growth in the world, the greatest source of which is animal production on farms [6]. The case is similar in EU member states, where the largest amount of emissions also comes from animal production. During 2004-2017, GHG emissions were highly concentrated in several EU member states; these were the countries with the most developed agriculture: France, Germany, Spain, and the United Kingdom [10].

There is a strong emphasis on the need to reduce greenhouse gas emissions in agriculture and to incorporate agriculture in actions against unfavorable climate change [2,11]. According to the Ministry of Climate, in Poland in 2018, agriculture was responsible for $8 \%$ of greenhouse gas emissions (in $\mathrm{CO}_{2}$ equivalent) with respect to the base in 1988 [12]. Although it is necessary, reducing GHG emissions in this sector remains an enormous challenge. This is because there is a specific conflict of interest in this area. Agricultural holdings are subject to competition in the food market, and reconciling economic and environmental interests is a problem. Unfortunately, the magnitude of GHG emissions from agriculture is disturbing. In Poland in 2018, a 7.2\% increase in GHG emissions from agriculture was recorded with respect to 2015 [13]. The search for effective tools for production technology management in order to consume fewer resources and reduce the environmental impact is ongoing [14]. It seems that only deep changes in the structure of the entire agri-food system can reduce greenhouse gas emissions in the agricultural sector [15]. This is not only about the practices employed in agricultural production, but also changes in consumers' nutritional habits; for example, research conducted in Mediterranean regions indicates that reducing meat and dairy consumption by $40 \%$ could reduce GHG emissions by $20-30 \%$ [16].

Transforming the economy into a low-emissions economy is currently one of the most important challenges facing the modern world. A circular, low-emissions economy plays a critical role in the development of agriculture, as it is an opportunity to improve both the quality of the environment and economic well-being. The social aspect of the low-emissions economy is highlighted. Limiting greenhouse gas emissions brings about benefits in terms of human health regardless of the level of prosperity, as the benefits apply to both rich societies and less affluent ones [17]. The economic dimension of the relationship between agriculture and climate change is also important. A slight reduction in GHG emissions resulting from the growth of value added in agriculture and renewable energy was observed in studies conducted in Pakistan [18]. The authors of that research suggest that increasing the value added of agriculture and consumption of renewable energy could counterbalance the increased GHG emissions resulting from the consumption of coal-generated electricity. Zafeiriou et al. [19] obtained divergent results in their research 
on the relationship between greenhouse gas emissions from agriculture and per capita income in the agricultural sectors of different EU countries. The results indicated that if $\mathrm{CO}_{2}$ emissions rise, so would income from agriculture, which was confirmed in the case of Spain. However, the authors expressed a reservation regarding the nonlinear relationship between agricultural income and $\mathrm{CO}_{2}$ emissions. Other studies indicate a positive influence of direct foreign investment in agriculture on the $\mathrm{CO}_{2}$ emission equivalent in developing countries [20]. The economic aspects of greenhouse gas reduction are rarely raised in studies. A report by the Centre for Climate and Energy Analyses unequivocally shows that reducing methane and nitrous oxide emissions from agriculture in Poland causes changes in farmers' level of production and income, and should be considered through the lens of economic effects [21]. At the same time, the report's authors are aware of how difficult it is to reach a compromise between these two objectives.

The assessment of agriculture's environmental impact is part of the concept of sustainable development. Studies concerning the impact of farms with different production profiles on the environment are an important part of this. It seems that such assessment is important because the impact of an agricultural holding on the environment depends on its specialization. Specialized farms are the ones that determine the basic trend of transformation in Polish agriculture. Specialization is a factor that fosters improvement of farming efficiency; however, there are environmental limitations linked to the growth of such farms. In such cases, activity is associated with the concentration of resources and intensity of production, so the environmental impact assessment is multi-dimensional. Various environmental and economic sustainability indicators are taken into account in such assessments [22-27]. The choice of indicator generally depends on the availability of data. In most assessments, greenhouse gas emissions are either omitted or treated as a side note. The relationships between environmental practices and economic results have also been insufficiently investigated. The present paper broadens the knowledge in this scope. Farmers, even those with the highest environmental awareness, will always be motivated by an economic objective in their activity. Thus, it is necessary to account for economic aspects in analyses of greenhouse gas emissions. Doing so can provide a broader picture of the dependencies existing between the farmer's choice of agricultural practices and the realization of the environmental objective, i.e., reducing methane and nitrous oxide emissions from agriculture.

The goals of the study were to estimate methane and nitrous oxide emissions at the level of an individual farm and indicate differences in emissions depending on the type of production, and to investigate dependencies between greenhouse gas emissions and economic indicators. The authors' intent is to present estimates of $\mathrm{CH}_{4}$ and $\mathrm{N}_{2} \mathrm{O}$ for three types of specialized agricultural holdings and to indicate the relationships between the economic objectives that motivate farms and the environmental objectives that arise from concern for the natural environment.

\section{Methodology}

Data concerning farms were obtained from the Farm Accountancy Data Network (FADN), published by the Institute of Agricultural and Food Economics, Polish Research Institute [28]. The data used in this research are not available in other databases. They concern agricultural accountancy, and hence are focused mainly on economic categories and the financial situation of individual farms; however, they can also be used for environmental analyses [29-31]. For the purposes of this study, we adopted the methodology described by Wiśniewski [7], who proposed assessing the magnitude of greenhouse gas emissions based on data from public statistics. The proposed solution complies with the methodology and standard indicators of the Intergovernmental Panel on Climate Change [32] and accounts for emission indicators developed by the National Centre for Emissions Management [33]. Other authors have also used data from public statistics to estimate emissions, including methane and nitrous oxide emissions [34-36]. 
Although the applied methodology is a simplified solution, it makes it possible to utilize generally available data on agricultural holdings and assess the impact of farming on the environment. Such a solution makes it possible to assess the variability of emissions and compare farms with respect to criteria such as farm size, production system, and type of production. Dick et al. [37] point to the advantages of such a solution, mainly from a practical perspective. Above all, it enables farmers to apply the best practices, select a method of production, and choose the means of its implementation.

The data come from 2004 to 2018. Three types of agricultural holdings were considered in the analyses: those that specialize in field crops, specialize in milk production (dairy cattle), or have a mixed production profile. These are the main types of farms in Poland. Data on the number and basic characteristics of farms are presented in Tables A1 and A2 (Appendix A) It should be noted that the number of farms changes every year, which is due to the selection of the sample included in the FADN system. Every year, some farms remain outside of FADN's area of observation, and other farms enter the sample.

Research was focused on the three main sources of greenhouse gas emissions, emitted directly over the course of agricultural production: gastrointestinal fermentation in farm animals (main source of methane emissions), animal feces (source of methane and nitrous oxide emissions), and nitrous oxide emissions from the use of mineral fertilizers.

Estimates of the magnitude of methane and nitrous oxide emissions from animal production were made based on the number of livestock and emission coefficients. In the case of cattle, available national gut fermentation $\mathrm{CH}_{4}$ emission coefficients applied by KOBiZE are used to prepare annual inventory reports. They are prepared based on daily energy demand for selected categories of cattle and coefficients of conversion to methane (share of energy in fodder converted to methane). Methane emission indicators from the livestock's gut fermentation is estimated based on the more general, default indicators recommended by the IPCC [32]. The level of nitrous oxide is estimated based on default indices of nitrogen content in animal feces and default $\mathrm{N}_{2} \mathrm{O}-\mathrm{N}$ emission coefficients for different methods of animal feces management [32]. The following emissions coefficients were applied ( $\mathrm{kg}$ per animal per year): $\mathrm{CH}_{4}$ from gastrointestinal fermentation: dairy cows, 122.0; other cattle, 49.65 ; swine, $1.5 ; \mathrm{CH}_{4}$ from feces: dairy cows, 11.87; other cattle, 2.15; swine, 3.07; nitrogen excreted in feces: dairy cows, 70.26; other cattle, 49.95; swine, 30.22 [7]. In FADN data, animals are counted as livestock units, which was why there was a need to convert these units into physical headcounts. This was done according to coefficients for conversion of cattle and swine, with the following coefficients adopted: dairy cows, 1.0; swine, 0.25 ; other cattle, 0.40 (mean value determined for heifers and calves) [38]. Poultry was omitted in the calculations due to the lack of IPCC guidelines.

The amounts of methane and nitrogen emissions were then calculated per 1 ha of farmland. The reference to farmland area was made for two reasons. First, when conducting a comparative analysis of three types of specialized farms, one needs to accept a single point of reference, and that is farmland area. Second, this made it possible to investigate dependencies between methane and nitrous oxide emissions and economic results, which was the intended goal of this work.

The average consumption of fertilizers per ha of farmland was adopted as the basis for estimating nitrous oxide emissions from mineral fertilizers. There is no information in the generally available FADN data about the consumption of mineral fertilizers, which is why this quantity was estimated indirectly based on average NPK consumption at individual farms in the country according to the Central Statistical Office [39]. The quantity of NPK consumption in the studied agricultural holdings was corrected by the indicator representing the general production and economic advantage of the studied farms over individual farms in Poland, collectively, as applied by the Institute of Agricultural and Food Economics [40]. This indicator was determined for every year based on a comparison of the production value per 1 ha of farmland of the most important products (basic cereals, potatoes, milk, and pig livestock) of the studied farms, with the production value of these products for the collective of farms, according to the Central Statistical Office, accepted as 1. 
It is accepted that farms that conduct agricultural accountancy achieve higher production and economic results than average farms in the region and in the country.

When estimating amounts of emissions from the use of mineral fertilizers, the default nitrous oxide emission coefficient of $0.01 \mathrm{~kg} \mathrm{~N} \mathrm{~N}_{2} \mathrm{O}-\mathrm{N}$ per $1 \mathrm{~kg} \mathrm{~N}$ was accepted. The mass of nitrogen originating from the application of mineral fertilizers was corrected by the amounts of ammonia and nitrous oxides emitted [7].

The following indicators were also applied to evaluate the economic situation of agricultural holdings: net value added (PLN $\cdot \mathrm{AWU}^{-1}$ ), family farm income (PLN), family farm income per 1 ha of farmland (PLN), and land productivity per 1 ha of farmland (PLN).

The arithmetic mean, minimum, maximum, and standard deviation were used to present results from 15 years of observation. Based on economic indicators originating from the described farms and emission values calculated for the selected greenhouse gases, an attempt was made to present the variation of these indicators over the course of those 15 years. Thirteen features describing the economic and agrarian characteristics of farms, along with the number of farms with a given agricultural production profile taking part in FADN studies, were taken as variables and subjected to reduction during analysis. The number of farms is not a feature associated with emissions, and in normal studies with repetitions, it should not be taken for analysis. Here, however, FADN studies were based on a variable number of farms, therefore, this feature could justify variation within the very short time period of one year. Ten indicators of GHG emissions were also taken as variables for analysis. The set of input data consisted of 23 features, representing the dimensions of the three described types of farms over 15 years, which were treated as objects in the analysis (Table 1).

Table 1. Values of variables used in the analysis (for three types of farms).

\begin{tabular}{|c|c|c|c|c|c|c|}
\hline \multirow[b]{2}{*}{ Specification } & \multicolumn{2}{|c|}{ A-Field Crops } & \multicolumn{2}{|c|}{ B-Milk } & \multicolumn{2}{|c|}{ C-Mixed } \\
\hline & Average & $\begin{array}{l}\text { Standard } \\
\text { Deviation }\end{array}$ & Average & $\begin{array}{l}\text { Standard } \\
\text { Deviation }\end{array}$ & Average & $\begin{array}{c}\text { Standard } \\
\text { Deviation }\end{array}$ \\
\hline \multicolumn{7}{|l|}{ Economic Indicators } \\
\hline $\mathrm{X}_{1}-$ Number of farms & 3058.20 & 680.01 & 1881.67 & 870.35 & 4011.20 & 500.67 \\
\hline $\mathrm{X}_{2}$-Utilized agricultural area (ha) & 30.51 & 10.38 & 19.13 & 2.96 & 16.83 & 1.32 \\
\hline $\mathrm{X}_{3}$-Total livestock unit (LU) & 2.42 & 1.22 & 20.17 & 4.50 & 12.47 & 1.09 \\
\hline $\mathrm{X}_{4}$-Total output (PLN) & $128,122.07$ & $54,478.53$ & $115,330.67$ & $38,910.40$ & $82,903.47$ & $17,700.99$ \\
\hline $\mathrm{X}_{5}$-Total inputs (PLN) & $110,920.67$ & $43,201.69$ & $88,252.33$ & $30,940.41$ & $77,282.40$ & $20,966.41$ \\
\hline $\mathrm{X}_{6}$-Fertilizers (PLN) & $21,068.53$ & $10,469.06$ & 7914.53 & 3043.14 & 7583.80 & 2310.94 \\
\hline X_Energy (PLN) & $13,366.07$ & 6218.51 & 9342.87 & 3264.85 & 7747.00 & 2085.39 \\
\hline $\mathrm{X}_{8}$-Total intermediate consumption (PLN) & $76,011.67$ & $30,406.09$ & $65,534.33$ & $22,908.43$ & $57,296.93$ & $14,988.95$ \\
\hline $\mathrm{X}_{9}-$ Total inputs $\left(\mathrm{PLN} \mathrm{ha}^{-1}\right)$ & 3593.80 & 503.97 & 4468.67 & 1006.58 & 4598.40 & 944.21 \\
\hline $\mathrm{X}_{10}-$ Land productivity $\left(\mathrm{PLN} \mathrm{ha}^{-1}\right)$ & 4117.87 & 514.65 & 5873.73 & 1236.60 & 4890.93 & 734.48 \\
\hline $\mathrm{X}_{11}$-Farm net value added (PLN AWU ${ }^{-1}$ ) & $34,984.33$ & $17,023.93$ & $29,603.73$ & $11,186.76$ & $17,554.33$ & 4079.47 \\
\hline $\mathrm{X}_{12}$-Family farm income (PLN) & $46,797.33$ & $28,032.23$ & $48,952.87$ & $19,791.13$ & $22,283.53$ & 5290.34 \\
\hline $\mathrm{X}_{13}$-Family farm income (PLN $\cdot \mathrm{ha}^{-1}$ ) & 1442.53 & 372.45 & 2480.40 & 714.25 & 1325.73 & 313.05 \\
\hline \multicolumn{7}{|l|}{ Indicators of GHG sources } \\
\hline $\mathrm{Z}_{1}$-Dairy cattle $\mathrm{CH}_{4}\left(\mathrm{~kg} \mathrm{y}^{-1}\right)$ & 55.16 & 42.16 & 1825.33 & 287.15 & 337.35 & 65.07 \\
\hline $\mathrm{Z}_{2}$-Dairy cattle $\mathrm{N}_{2} \mathrm{O}\left(\mathrm{kg} \mathrm{y}^{-1}\right)$ & 28.95 & 22.13 & 958.11 & 150.87 & 177.05 & 34.15 \\
\hline $\mathrm{Z}_{3}$-Other cattle $\mathrm{CH}_{4}\left(\mathrm{~kg} \cdot \mathrm{y}^{-1}\right)$ & 86.67 & 28.41 & 797.43 & 326.89 & 446.06 & 133.44 \\
\hline $\mathrm{Z}_{4}$-Other cattle $\mathrm{N}_{2} \mathrm{O}\left(\mathrm{kg} \mathrm{y}^{-1}\right)$ & 83.58 & 27.39 & 769.60 & 315.28 & 430.13 & 128.67 \\
\hline $\mathrm{Z}_{5}$-Pigs $\mathrm{CH}_{4}\left(\mathrm{~kg} \mathrm{y}^{-1}\right)$ & 19.49 & 12.33 & - & - & 107.41 & 10.86 \\
\hline $\mathrm{Z}_{6}$-Pigs $\mathrm{N}_{2} \mathrm{O}\left(\mathrm{kg} \mathrm{y}^{-1}\right)$ & 123.37 & 76.15 & - & - & 709.30 & 71.78 \\
\hline $\mathrm{Z}_{7}$-Total emissions $\mathrm{CH}_{4}\left(\mathrm{~kg} \mathrm{y}^{-1}\right)$ & 154.07 & 86.20 & 2622.75 & 611.07 & 890.82 & 102.46 \\
\hline $\mathrm{Z}_{8}$-emissions $\mathrm{CH}_{4}\left(\mathrm{~kg} \mathrm{ha}^{-1}\right)$ & 5.96 & 4.07 & 135.94 & 14.25 & 76.37 & 6.80 \\
\hline $\mathrm{Z}_{9}$-total emissions $\mathrm{N}_{2} \mathrm{O}\left(\mathrm{kg} \mathrm{y}^{-1}\right)$ & 239.89 & 116.65 & 1727.71 & 464.10 & 1317.15 & 122.23 \\
\hline $\mathrm{Z}_{10}$-emissions $\mathrm{N}_{2} \mathrm{O}\left(\mathrm{kg} \mathrm{ha}^{-1}\right)$ & 9.27 & 5.65 & 89.04 & 12.15 & 78.30 & 4.26 \\
\hline
\end{tabular}


Three independent analyses were carried out for each type of farm. Factor analysis was conducted using principal component analysis (PCA) [41,42]. To facilitate the interpretation of results, varimax rotation was applied. This involves rotation of the X-and Y-axes (linear combination) so as to maximize the variance of loadings between factors and minimize their variance within the new factor called a component here.

\section{Results}

The level of greenhouse gas emissions was dependent on the production profile and was characterized by high variation during the studied period (Figure 1). Farms specializing in milk production emitted the most $\mathrm{CH}_{4}$ and $\mathrm{N}_{2} \mathrm{O}$. This is the result of high livestock density and intensive production technology. Farms specializing in milk production surpassed other types of farms in terms of the amount of income from the farm and land productivity (Table A2, Appendix A). At field crop farms, the levels of methane and nitrous oxide emissions were the lowest among the studied farms. This is due to the specialization adopted and consistent reduction of animals on the farm. During the period of study, changes in the levels of $\mathrm{CH}_{4}$ and $\mathrm{N}_{2} \mathrm{O}$ occurred at all farms and were associated with organizational changes at the farms. There is a positive correlation between methane and nitrous oxide emissions and economic results measured at the level of family farm income. Milk farms reached the highest land productivity and the highest income level per 1 ha of farmland.

On farms that specialize in field crops, the average methane emissions amounted to $5.96 \mathrm{~kg} \cdot \mathrm{ha}^{-1}$, varying within a range of 0.25 to 11.3 . Within the studied time interval, several periods of lesser and greater $\mathrm{CH}_{4}$ emissions can be distinguished (Figure 1A). After a period of slight decrease in the level of emissions during 2005-2006, there was an increase during the next two years (2008-2009) to a level of $11.31 \mathrm{~kg} \cdot \mathrm{ha}^{-1}$. In the following years, a declining tendency can be seen, and in 2018, total $\mathrm{CH}_{4}$ emissions per 1 ha of farmland was more than three times lower than in 2004. During the studied time interval, the period of 2010-2012 is noteworthy as greenhouse gas emissions were very low during that time. The factor responsible for this was the selection of farms that were within FADN's area of observation during those years. These were much larger farms and the average area of farmland was twice as large as in other years.

The level of emissions should also be considered against the backdrop of organizational changes in agricultural holdings, particularly with regard to animal production. In 2004, the average number of animals on a farm in livestock units amounted to $3.51 \mathrm{LU}$ (1.6 of cattle and 1.91 of swine). This number decreased every year after that $\left(R^{2}=0.7706\right)$. In 2018 , the number of animals was reduced to $0.09 \mathrm{LU}$ of dairy cattle (which can be considered as total elimination), $0.55 \mathrm{LU}$ of other cattle and $0.43 \mathrm{LU}$ of swine. Organizational changes in the studied group of farms indicate progressing specialization. These farms specialize in field crops. The first few years were a period of adaptation to the selected production profile and many holdings continued to raise animals. In every year that followed, farms reduced animal production in favor of field crops according to the specialization they adopted.

In the case of dairy cattle farms, $\mathrm{CH}_{4}$ emissions were substantially higher ranging from 119.90 to $157.73 \mathrm{~kg} \cdot \mathrm{ha}^{-1}$ depending on the year. Throughout the entire period of study, the level of emissions stayed at a relatively constant level and systematically increased starting from 2013 (Figure 1B). The causes of this situation are understandable. These holdings specialize in milk production, and over the course of successive years, farmers increased their herds of dairy cows $\left(\mathrm{R}^{2}=0.9663\right)$. The average number of cows on a farm in 2004 amounted to $10.69 \mathrm{LU}$, and in 2018, the number was $17.12 \mathrm{LU}$. This is the basic production herd, and in the case of farms specializing in milk production, the scale of production is fundamentally important in terms of farming economics. Besides cattle in the basic herd, other functional groups of cattle were also present, most likely constituting a replacement herd. This population of cattle also increased from year to year. In the case of this group of holdings, the total magnitude of emissions originated from cattle raising (there were no other animal species). 

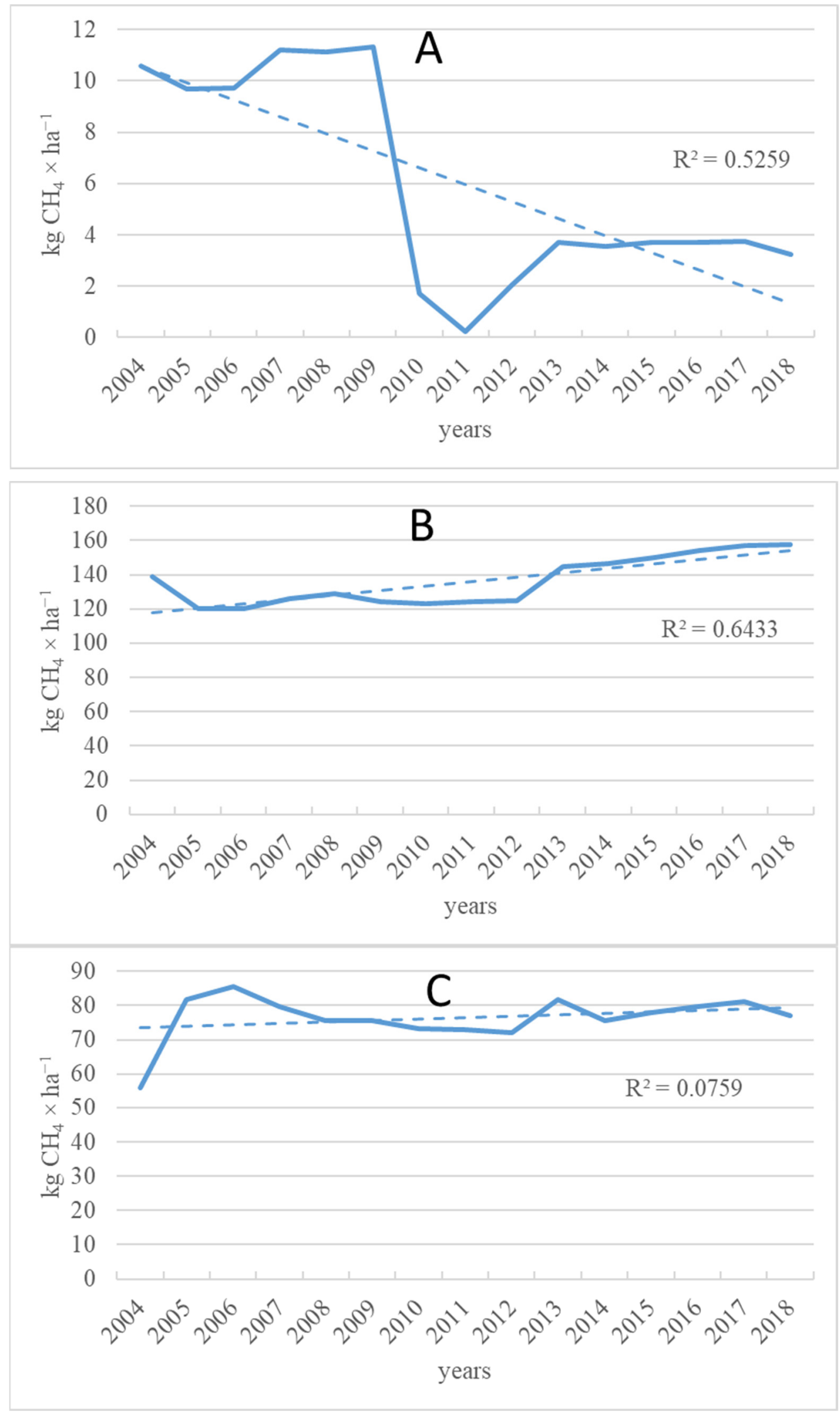

Figure 1. Emission levels of $\mathrm{CH}_{4}\left(\mathrm{~kg} \cdot \mathrm{ha}{ }^{-1}\right)$ at three types of farms: (A) Field crops; (B) Milk; (C) Mixed. 
For holdings with a mixed profile, $\mathrm{CH}_{4}$ emissions were at a moderate level. If we accept the level of $\mathrm{CH}_{4}$ emissions at dairy cow holdings to be 1, then farms specializing in field crops were at a level of 0.045 on average during the studied period and mixed holdings were at a level of 0.57. During the studied period, the amount of $\mathrm{CH}_{4}$ emissions changed from 56.09 to $85.67 \mathrm{~kg} \mathrm{ha}^{-1}$. The level of this gas exceeded $80 \mathrm{~kg} \cdot \mathrm{ha}^{-1}$ in only four years (Figure 1C).

The amount and changes of $\mathrm{CH}_{4}$ emissions should be considered against the backdrop of the way animal production was organized. During 2004-2005, over half of $\mathrm{CH}_{4}$ emissions originated from dairy cattle, and the number of cattle was the greatest during those years. However, starting from 2006, the number of cows was successively reduced and herds of beef cattle were enlarged. These changes are reflected in the structure of $\mathrm{CH}_{4}$ emission sources. In 2018 , over $65 \%$ of emissions originated from the raising of beef cattle. In total, cattle were responsible for $85-90 \%$ of $\mathrm{CH}_{4}$ emissions depending on the year. In terms of swine herds, changes in herd populations were small, and they were responsible for approximately $12 \%$ of methane emissions on average during the studied period; this level declined in the years that followed.

The analysis performed indicates that holdings with a mixed profile raised both cattle and swine, however, in recent years, they became more oriented toward raising beef cattle. These changes were reflected in greenhouse gas emissions. Regardless of the production profile, gastrointestinal fermentation in cattle is mainly responsible for methane emissions. Cattle were responsible for $82.5 \%$ of methane emissions on mixed farms and up to $92 \%$ on dairy farms. Accordingly, 8-17.5\% of methane emissions originated from animal feces. Animal production is also a source of nitrous oxide emissions via feces. $\mathrm{N}_{2} \mathrm{O}$ emissions were higher for farms with larger animal herds (Figure 2).

Farms that specialize in milk production produce the most nitrous oxide emissions, taking into account nitrous oxide from animal feces and mineral fertilization at a level of $90.06 \mathrm{~kg} \mathrm{~N}_{2} \mathrm{O} \mathrm{ha}^{-1}$ (Figure 2B). Meanwhile, on mixed farms, the value of nitrous oxide emissions was $78.96 \mathrm{~kg} \mathrm{~N}_{2} \mathrm{O} \cdot \mathrm{ha}^{-1}$, and on farms specializing in field crops it was $9.65 \mathrm{~kg}$ $\mathrm{N}_{2} \mathrm{O} \mathrm{ha}^{-1}$. These data indicate that cattle are the main emitters of not only methane but also nitrous oxide. On dairy farms, $93-95 \%$ of $\mathrm{N}_{2} \mathrm{O}$ emissions originated from animal feces. On field crop farms, $\mathrm{N}_{2} \mathrm{O}$ emissions mainly originated from mineral fertilization. Animals were kept solely for the family's own needs (0.09 LU dairy cattle and 0.55 LU other cattle in 2018).

Data on nitrous oxide emissions from the application of mineral fertilizers indicate that the greatest emissions came from farms that specialize in milk production. This is the result of intensive fertilization of cultivated plants. Corn, which constitutes the main feed base for cattle, is dominant in the crop structure. During the studied period, the area of corn cultivation increased from 0.3 ha in 2004 to 14.24 ha in 2018, while the area of cereals changed from 5.39 ha to 7.49 ha. During this period, consumption of mineral fertilizers increased from 163 to $271 \mathrm{~kg} \mathrm{NPK} \cdot \mathrm{ha}^{-1}$.

The amount of nitrous oxide emissions from mineral fertilizers on mixed farms was $65 \%$ of the amount on dairy cattle farms. During the studied period, the level of $\mathrm{N}_{2} \mathrm{O}$ emissions was variable, and it is difficult to unequivocally identify a trend (Figure 2C). The highest level of emissions was recorded in 2006 at $86.31 \mathrm{~kg} \mathrm{~N}_{2} \mathrm{O}$ ha ${ }^{-1}$ and the lowest in 2012 at $72.64 \mathrm{~kg} \mathrm{~N}_{2} \mathrm{O}$ ha $^{-1}$ per farm. Consumption of mineral fertilizers increased during the studied period from 132 to $152 \mathrm{~kg} \mathrm{NPK} \cdot \mathrm{ha}^{-1}$ per farm.

The lowest level of $\mathrm{N}_{2} \mathrm{O}$ emissions from mineral fertilizers was noted on farms that specialize in field crops (Figure 2A). Emissions from field crop farms amounted to 35\% of dairy farm emissions and 55\% of mixed farm emissions. Field crop farms applied less mineral fertilization than the other studied groups. Fertilizer consumption ranged from 76 to $98 \mathrm{~kg} \mathrm{NPK} \mathrm{ha}^{-1}$ depending on the year. 


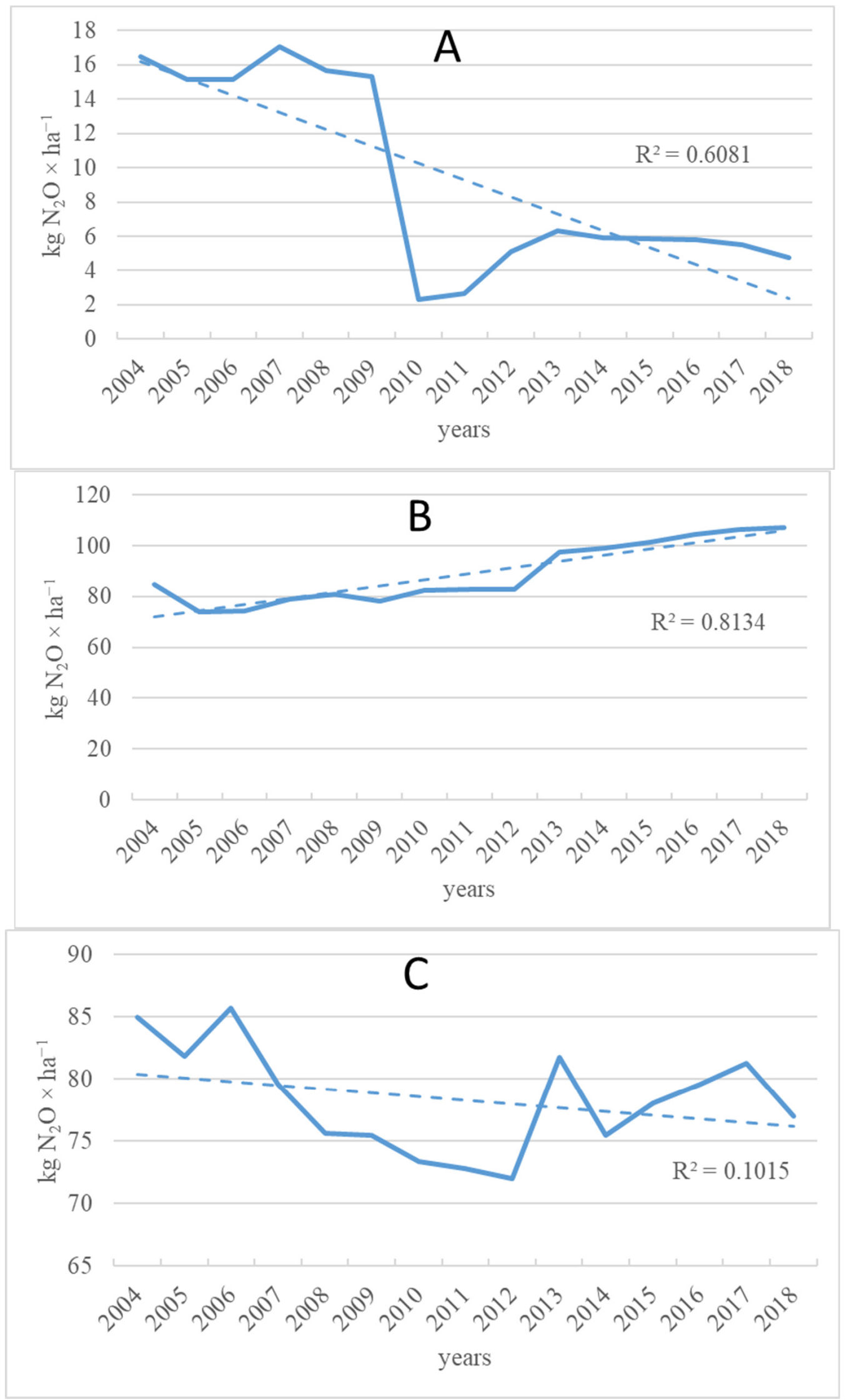

Figure 2. Emission levels of $\mathrm{N}_{2} \mathrm{O}\left(\mathrm{kg} \cdot \mathrm{ha}^{-1}\right)$ at different types of farms: (A) Field crops; (B) Milk; (C) Mixed. 
Reducing the 23 dimensions representing the primary features introduced for analysis in the case of dairy cattle farms, 21 dimensions (absence of swine herd) distinguished just one principal component responsible for $91.35 \%$ of total variation. This demonstrates that these farms are highly specialized in this production. All undertakings associated with activities described by the studied features had an equally strong impact on emissions of selected greenhouse gases over the course of the 15-year period. After applying varimax rotation, two principal components were distinguished: PC1 (57.39\%) and PC2 (38.26\%) (Figure 3, Table A3, Appendix A). After varimax rotation, the assignment of the majority of features to PC1 remained unchanged with the exception of $\mathrm{CH}_{4}$ and $\mathrm{N}_{2} \mathrm{O}$ emissions per 1 ha.

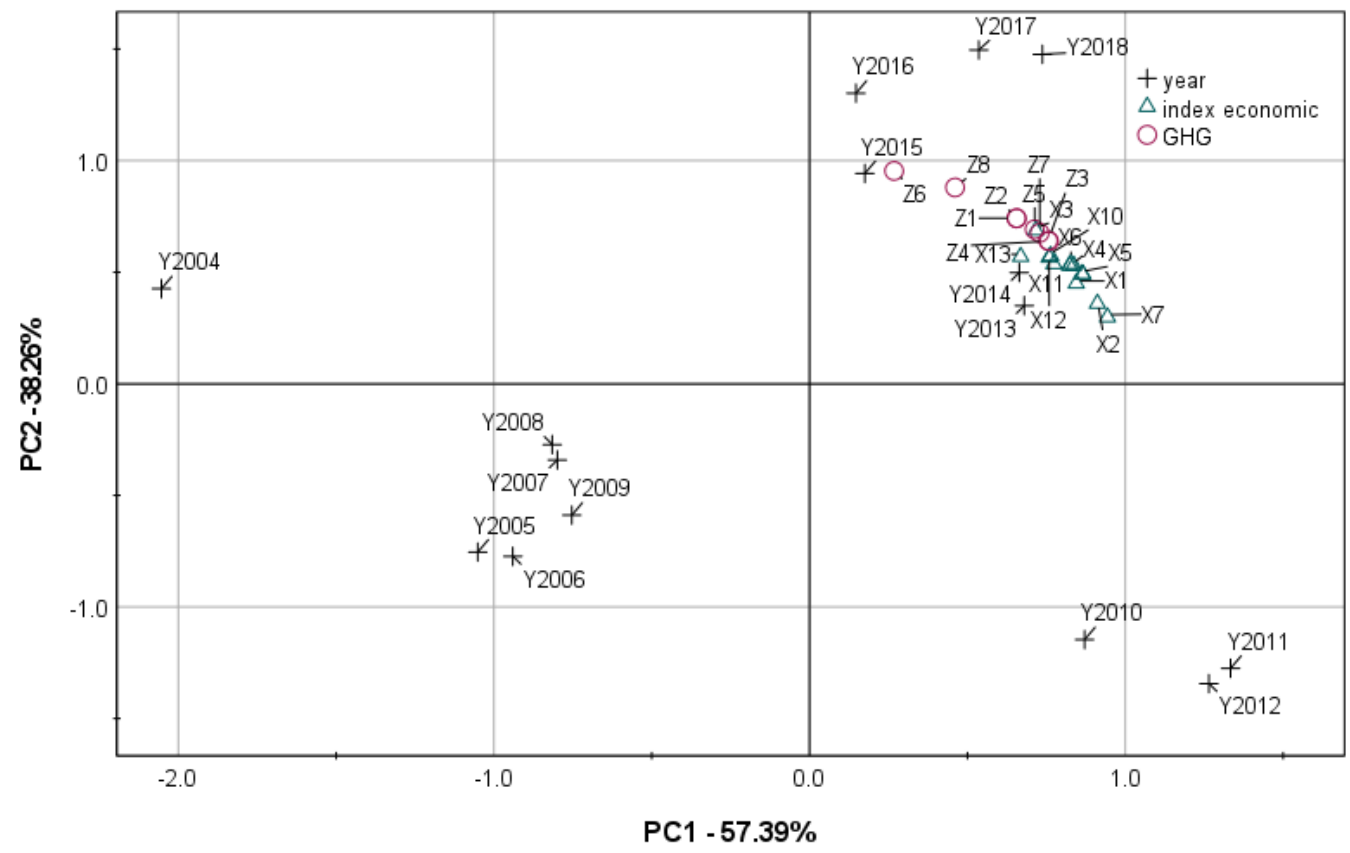

Figure 3. Relationships of locations of studied sources of $G H G$ emissions $\left(Z_{1} \ldots . Z_{4} Z_{7} \ldots . . Z_{10}\right)$ and economic indicators $\left(X_{1} \ldots . X_{13}\right)$ for farms with milk production in the studied years (Y2004 ... Y2018) in the space of the first two components, PC1 and PC2.

Similar to farms with a mixed production profile, field crop farms are characterized by diverse factors that influence total GHG emissions. Principal component analysis clearly differentiated the studied features into three principal components describing total variation. The first component was responsible for $41.19 \%$ of total variation and the features most strongly correlated with it included $\mathrm{CH}_{4}$ and $\mathrm{N}_{2} \mathrm{O}$ emissions from each group of animals, total $\mathrm{CH}_{4}$ and $\mathrm{N}_{2} \mathrm{O}$ emissions, and number of animals.

The second component explained $39.64 \%$ of total variation (Figure 4, Table A4, Appendix A) and was most strongly correlated with the following economic indicators: total family farm income (PLN) and income per 1 ha of farmland, as well as net value added (PLN.AWU ${ }^{-1}$ ), total output (PLN), farmland area (ha), energy (PLN), intermediate consumption (PLN), total inputs (PLN), and mineral fertilizers (PLN). The third component explained $15.64 \%$ of total variation and was most strongly correlated with land productivity (PLN ha ${ }^{-1}$ ) and total inputs (PLN ha ${ }^{-1}$ ). 


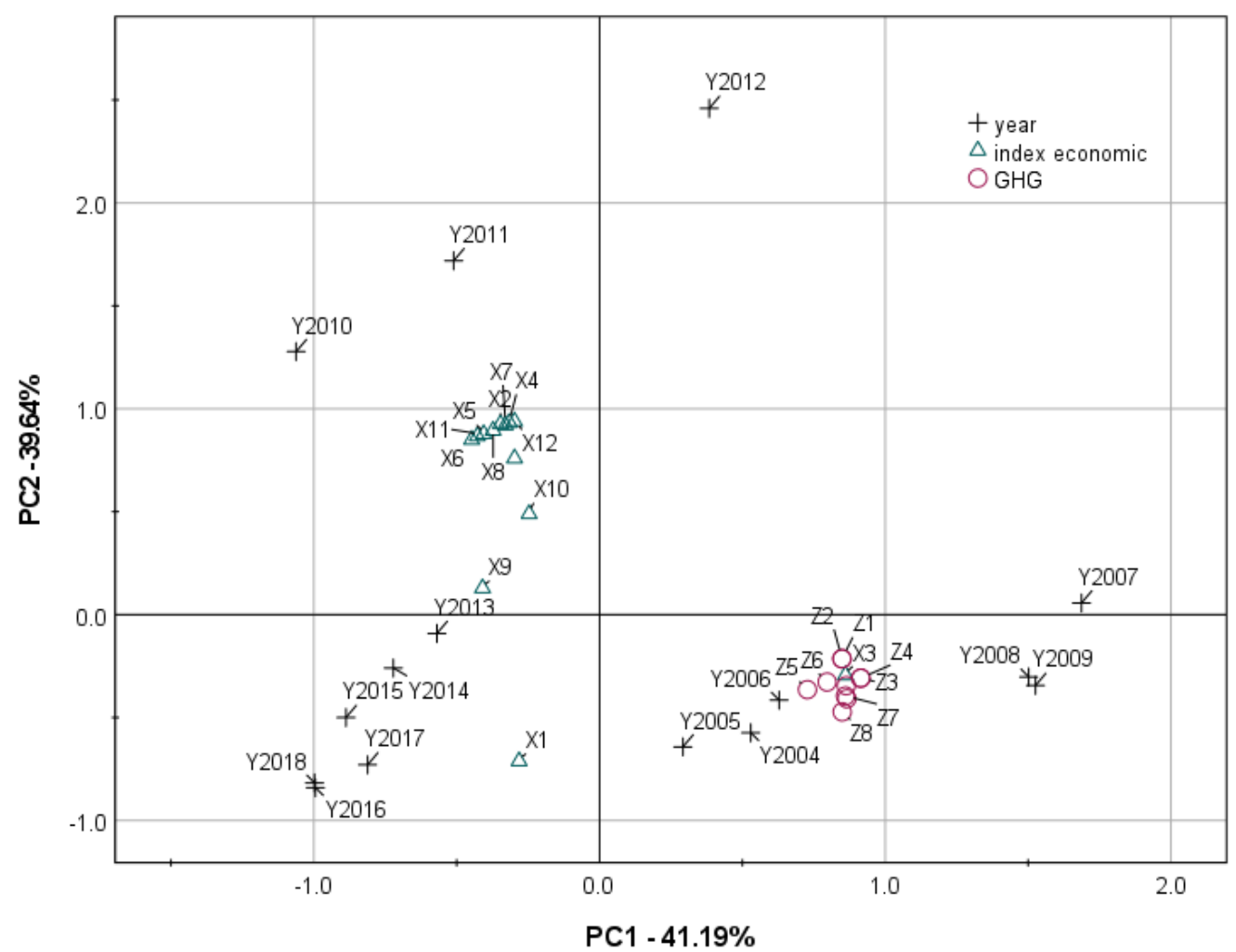

Figure 4. Relationships of locations of examined indices $\left(Z_{1} \ldots . . Z_{10}\right)$ of $G H G$ emissions and economic indices $\left(X_{1} \ldots . X_{13}\right)$ for field crop farms in the studied years (Y2004 .... Y2018) in the space of the first two components, PC1 and PC2.

Mixed production farms are characterized by diverse factors influencing total $\mathrm{CH}_{4}$ and $\mathrm{N}_{2} \mathrm{O}$ emissions. Principal component analysis clearly differentiated the studied features into four principal components describing total variation. The first component explained $48.83 \%$ of total variation and was most strongly correlated with variables including farmland area (ha), livestock units (LU), total production (PLN), total inputs (PLN), mineral fertilizers (PLN), energy (PLN), intermediate consumption (PLN) and total inputs $\left(\mathrm{PLN} \cdot \mathrm{ha}^{-1}\right)$ as well as land productivity (PLN.ha ${ }^{-1}$ ), net value added (PLN.AWU $\left.{ }^{-1}\right), \mathrm{CH}_{4}$ and $\mathrm{N}_{2} \mathrm{O}$ emissions originating from cattle groups other than dairy cows, and total $\mathrm{CH}_{4}$ and $\mathrm{N}_{2} \mathrm{O}$ emissions. The second component explained $22.55 \%$ of total variation and was most strongly correlated with variables including livestock units (LU) and $\mathrm{CH}_{4}$ and $\mathrm{N}_{2} \mathrm{O}$ emissions from dairy cattle and swine (Figure 5, Table A5, Appendix A). The variation explained by the first two components amounts to $71.38 \%$ of the total variation. The next components distinguished in the analysis were PC3, explaining $14.95 \%$. and PC4, explaining $8.33 \%$ of the total variation.

Statistical analysis confirmed the dependency between $\mathrm{CH}_{4}\left(\mathrm{Z}_{8}\right)$ and $\mathrm{N}_{2} \mathrm{O}\left(\mathrm{Z}_{10}\right)$ emissions and economic results: net value added $\left(X_{11}\right)$ and family farm income per 1 ha $\left(X_{13}\right)$. On dairy cattle farms, the value of $\mathrm{CH}_{4}$ and $\mathrm{N}_{2} \mathrm{O}$ emissions grew as the values of economic indicators increased. Net value added and family farm income (PLN.ha ${ }^{-1}$ ) were positively correlated with $\mathrm{CH}_{4}(\mathrm{r}=0.700$ and 0.700$)$ and $\mathrm{N}_{2} \mathrm{O}(\mathrm{r}=0.802$ and 0.774$)$ emissions (Table A7, Appendix A). On field crop farms, the dependency between net value added and $\mathrm{CH}_{4}$ and $\mathrm{N}_{2} \mathrm{O}$ emissions was negatively correlated $(\mathrm{r}=-0.814$ and -0.785$)$. Similarly, there was a negative dependency between family farm income (PLN.ha ${ }^{-1}$ ) and emissions of the studied greenhouse gases $(r=-0.695$ and -0.676$)$ (Table A6, Appendix A). On mixed farms, the dependency between economic indicators and $\mathrm{CH}_{4}$ and $\mathrm{N}_{2} \mathrm{O}$ emissions was negative, except the dependency between net value added and $\mathrm{CH}_{4}$ emissions $(\mathrm{r}=0.272)$ (Table A8, Appendix A). 


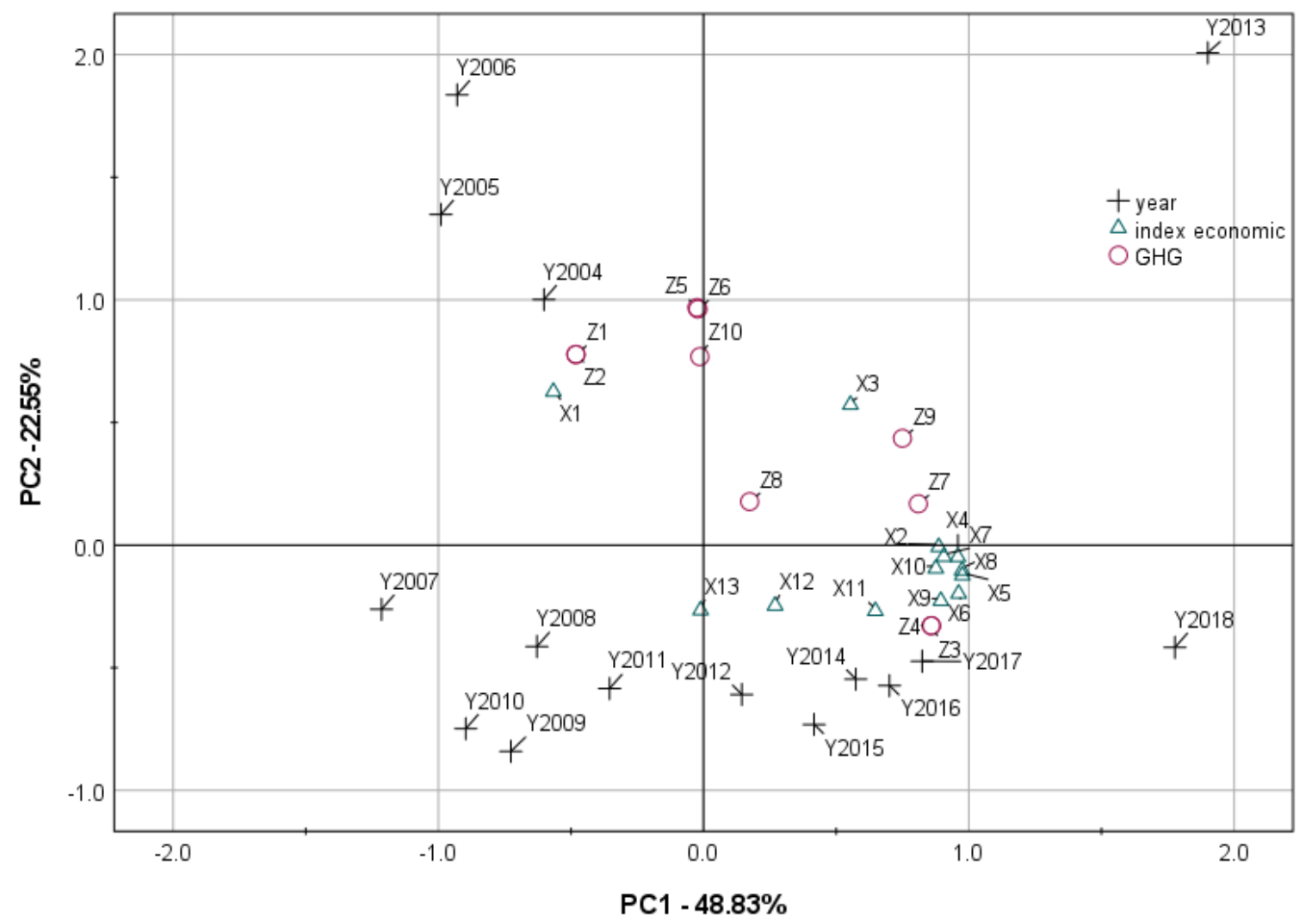

Figure 5. Relationships of locations of studied GHG emission sources $\left(Z_{1} \ldots . Z_{10}\right)$ and economic indicators $\left(X_{1} \ldots . . X_{13}\right)$ for mixed production farms in the studied years (Y2004 .... Y2018) in the space of the first two components, PC1 and PC2.

\section{Discussion and Conclusions}

The growing demand for food requires intensification of agricultural production, which has a negative impact on the environment. This impact contributes to depletion of energy carriers, global warming, and reduction of air quality [43,44]. In order to ensure sustainable development, we need to search for solutions that can conserve environmental values while enabling the achievement of economic goals. The agricultural ecosystem both emits and absorbs greenhouse gases, and because of this, we use the concept of net greenhouse gases [45].

The analysis results indicate that animals remain a strong determinant of GHG emissions. A particularly high level of emissions is associated with cattle raising, which was the case for dairy cattle holdings. The level of nitrous oxide emissions was also high, as a result of the application of intensive feed production technologies. This was also confirmed by principal component analysis (PCA). This indicates that on dairy cattle farms, the organization of both animal and plant production is completely subordinated to milk production. Emissions on mixed farms are the result of intensive animal and plant production. Meanwhile, on field crop farms, where animal production was successively reduced, emissions were the lowest and mainly pertained to crops. This was also confirmed by analyses conducted at the regional level [46]. In Poland, regions with a larger share of large agricultural holdings and animal production (the northeastern part of the country and the Wielkopolska region) are characterized by higher emissions levels $[7,36]$.

The values obtained in this research are higher than those obtained by other authors. According to Wiśniewski [7], 42\% of emissions originate from gastrointestinal fermentation in rural and urban-rural municipalities. In their investigations of emissions from agriculture in Africa, Tongwane et al. [6] determined that gastrointestinal fermentation was responsible for over half of all emissions originating from agriculture. Studies conducted in Ireland showed that $49 \%$ of emissions originated from gastrointestinal fermentation [47]. However, it should be noted that, in general, greenhouse gas emissions are estimated based on data for an average agricultural holding in the region or country and include all green- 
house gases. Meanwhile, our studies examined commodity farms that apply intensive technologies linked to specialization of production. In this case, we are dealing with concentrated means of production and high livestock density. These farms are distinguished against a background of so-called average farms by significantly higher production and economic results, but at the same time, they exert greater pressure on the environment. This hypothesis was confirmed by the research of Wysocka-Czubaszek et al. [36] concerning $\mathrm{CH}_{4}$ and $\mathrm{N}_{2} \mathrm{O}$ emissions in Poland. According to those authors, $51 \%$ of $\mathrm{CH}_{4}$ and $37 \%$ of $\mathrm{N}_{2} \mathrm{O}$ is emitted by three voivodeships where there is intensive agriculture: the Masovian and Podlaskie voivodeships, leading producers of milk and beef, and another voivodeship characterized by intensive production of animals and plants. The release of large amounts of methane and nitrous oxide is therefore the result of specialization which is associated with the concentration of agricultural holdings' resources.

The economic results obtained for field crop farms are concurrent with the results obtained by Khan et al. [18]. Growth of net value added and farm income per 1 ha of farmland caused a reduction of $\mathrm{CH}_{4}$ and $\mathrm{N}_{2} \mathrm{O}$ emissions. Meanwhile, on dairy cow farms, dependencies between economic results and gas emissions are different, confirming the results of Zafeirou et al. [19]. In this case, as value added and farm income increase, so do $\mathrm{CH}_{4}$ and $\mathrm{N}_{2} \mathrm{O}$ emissions. Syp and Osuch [31] obtained similar results in their investigations of organic and conventional farms. In their research, higher productivity was found on milk farms and was associated with higher GHG emissions. The view that farms which have more animals (conventional farms had more animals than organic farms) emphasize economic objectives, and that productivity is prioritized over environmental objectives, was also confirmed.

The results obtained indicate that the direction of dependencies between greenhouse gas emissions and economic results is determined by the presence of animal production. particularly cattle. Cattle are responsible for the highest emissions of $\mathrm{CH}_{4}$ [48].

The example of the three types of agricultural holdings described in this study confirms the hypothesis of the relationship between specialization of agricultural production and $\mathrm{CH}_{4}$ and $\mathrm{N}_{2} \mathrm{O}$ emissions. Dairy farms are the most harmful to the environment. Compared to farms of other types (field crop and mixed), they emit the highest amounts of $\mathrm{CH}_{4}$ and $\mathrm{N}_{2} \mathrm{O}$. This is the result of a high concentration of animals on the farm and intensive plant production for use as fodder. Farms of this type successfully implement their economic goals, with the highest net value added and farm income per area unit. Field crop farms are less harmful to the environment. Farms of this type have successively reduced their livestock production, resulting in lower $\mathrm{CH}_{4}$ and $\mathrm{N}_{2} \mathrm{O}$ emissions. In this case, the quality of the soil may deteriorate due to the lack of organic fertilization.

Intensive agriculture does not have to be a threat to the environment. Countries that have achieved sustainable agriculture have done so by developing large farms and a high level of mechanization [49]. It is expected that agriculture will satisfy the needs of the growing global population while contributing to the reduction of GHG emissions. Achieving this goal will require intensification of production with higher emissions per unit of land area but lower emissions per unit of agricultural production [50,51].

Reducing greenhouse gas emissions from agriculture requires the introduction of innovative technologies and tools to increase the efficiency of agricultural production. One effective method of limiting methane emissions is to use a cattle nutrition strategy. Studies confirm that methane emissions have been reduced as a result of the application of high-starch diets or exogenic enzymes. Supplementation with fats also yields good results. This indicates that appropriate diets can be implemented for dairy and beef cattle in order to reduce methane emissions without reducing productivity [52].

According to Hoglund-Isaksson et al. [53], the possibilities of reducing methane and nitrous oxide emissions from agriculture are limited and technological solutions are insufficient. Hence, they propose the introduction, by 2050, of institutional reforms and changes to human nutritional habits on a broad scale, in addition to the implementation of technological solutions. Meanwhile, Ockoet al. [54] believe that achieving a reduction 
of methane and nitrous oxide emissions by changing the human diet is less realistic than implementing technological strategies.

Specialization fosters the development of farms and builds competitive advantage. As research indicates, specialization is deepening, and economic goals are the decisive factor in the adoption of areas of specialization by agricultural holdings [55]. Farms with intensive animal production have the strongest impact with respect to the environment. Solutions that make it possible to reduce the pressure of agriculture on the environment while maintaining food security are already known. These are, above all, good agricultural practices, including no-till farming, breeding progress, and effective fertilizer management. Good management practices may reduce the burden on the environment and the costs of agricultural production. Economic instruments are also indicated for strategies to limit emissions, e.g., in the form of compensation for income lost due to reduced production intensity [56].

Was et al. [21] presented several scenarios of reduced methane and nitrous oxide emissions based on data describing the Polish agricultural sector in the base year 2015 . Changes in income levels are an important indicator from the perspective of analyzing the potential economic consequences of various scenarios of reduced greenhouse gases from agriculture. The process of reducing emissions in agriculture using currently known and available technologies is highly complex and inevitably leads to drops in production and income. According to these scenarios, the greatest drops in production and income are observed in the case of beef and dairy cattle. Plant production is the least sensitive to restrictions with respect to emissions.

The present research contributes to agricultural science and environmental economics by broadening the knowledge on the subject of relationships between intensive agricultural production and the environment, including the economic aspect, a subject raised infrequently in the literature. The present paper broadens the knowledge concerning the relationships between methane and nitrous oxide emissions and the economic results of agricultural holdings with different specializations. This research can serve as a basis for creating models for the development of agriculture. Research conducted until now has been on a regional scale $[7,36]$. Based on previous research, we can only make approximate inferences about the applied technologies in terms of their relationship with methane and nitrous oxide emissions. The advantages of the research in this paper, at the level of individual farms, are that it increases the accuracy of estimating greenhouse gas emissions and makes it possible to determine dependencies between emissions and economic results. Few analyses have raised these issues. Methods of reducing GHG emissions by changing production technology are necessary. These methods should contribute to improving environmental protection and reducing production costs. Specialized farms are and will continue to be the foundation of the country's food economy. The economic objective is the motivating factor for adopting a specialization. Therefore, a deeper understanding of environmental and economic relationships in agricultural production will make it possible to promote technological innovations leading to low emissions. Consequently, integrating all aspects of the low-emissions economy will contribute to raising the competitiveness of agricultural holdings.

This research also has practical value. It makes it possible to evaluate greenhouse gas emissions from agricultural production in a relatively simple way and to verify practices applied at the level of individual agricultural holdings and environmental protection.

\section{Limitations}

The authors are aware of the limitations of this analysis. One limitation is due to the choice of research subjects. The research subjects are commodity farms that are achieving higher results than average farms in Poland, which hinders the ability to generalize and make inferences. Another limitation is that the estimation of greenhouse gas emissions was done indirectly due to the lack of detailed data. There is a clear need to supplement databases with data allowing for environmental assessment of agricultural holdings. This has also been noted by other authors $[29,30]$. 
Yet another limitation is the limited number of production profiles. Further research should account for all production profiles adopted by farms and for their economic results. This is important with regard to the efficacy of methods of reducing methane and nitrous oxide emissions in agriculture.

Author Contributions: Conceptualization: Z.K.-C.; Methodology: L.S. and Z.K.-C.; Data curation: Z.K.-C.; Formal analysis: Z.K.-C. and L.S.; Investigation: L.S.; Z.K.-C. and R.T.; Supervision: Z.K.-C.; Writing - original draft: Z.K.-C. and L.S.; Writing—review and editing: Z.K.-C., L.S. and R.T. All authors have read and agreed to the published version of the manuscript.

Funding: This research received no external funding.

Data Availability Statement: Publicly available datasets were analyzed in this study. The data can be found here: https: / / fadn.pl/publikacje/wyniki-standardowe-2/wyniki-standardowe-sredniewazone/ (accessed on 13 March 2021).

Conflicts of Interest: The authors declare no conflict of interest.

\section{Appendix A}

Table A1. Number of farms in 2004-2018.

\begin{tabular}{|c|c|c|c|c|c|c|c|c|c|c|c|c|c|c|c|}
\hline \multirow{2}{*}{ Specification } & \multicolumn{15}{|c|}{ Year } \\
\hline & 2004 & 2005 & 2006 & 2007 & 2008 & 2009 & 2010 & 2011 & 2012 & 2013 & 2014 & 2015 & 2016 & 2017 & 2018 \\
\hline Field crops & 2573 & 2650 & 2622 & 2800 & 3241 & 3287 & 2047 & 2177 & 2303 & 3215 & 3342 & 3411 & 3893 & 4049 & 4263 \\
\hline Milk & 785 & 895 & 877 & 817 & 891 & 952 & 2319 & 2271 & 2302 & 2652 & 2735 & 2782 & 2749 & 2659 & 2539 \\
\hline Mixed & 4937 & 4614 & 4430 & 4470 & 4288 & 3967 & 3862 & 3785 & 3517 & 4282 & 4083 & 3942 & 3446 & 3352 & 3193 \\
\hline
\end{tabular}

Table A2. Descriptive statistics of farms.

\begin{tabular}{|c|c|c|c|c|}
\hline Specification & Average & Min. & Max. & SD \\
\hline \multicolumn{5}{|c|}{ Field Crops } \\
\hline Utilized agricultural area (ha) & 30.51 & 22.90 & 40.70 & 10.38 \\
\hline Total livestock unit (LU) & 2.42 & 1.20 & 4.00 & 1.22 \\
\hline Total output (PLN) & $128,122.07$ & $77,603.00$ & $261,535.00$ & $54,478.53$ \\
\hline Total inputs (PLN) & $110,920.67$ & $64,499.00$ & $204,878.00$ & $43,201.69$ \\
\hline Fertilizers (PLN) & $21,068.53$ & 10.157 .00 & 43.319 .00 & $10,469.06$ \\
\hline Energy (PLN) & $13,366.07$ & 7222.00 & $27,537.00$ & 6218.51 \\
\hline Total intermediate consumption (PLN) & $76,011.67$ & $44,856.00$ & $143,873.00$ & $30,406.09$ \\
\hline Total inputs (PLN ha ${ }^{-1}$ ) & 3593.80 & 2647.00 & 4092.00 & 514.65 \\
\hline Land productivity $\left(\mathrm{PLN} \mathrm{ha}^{-1}\right)$ & 4117.87 & 3117.00 & 5158.00 & 514.65 \\
\hline Farm net value added (PLN AWU $\left.{ }^{-1}\right)$ & $34,984.33$ & $15,352.00$ & $73,098.00$ & $17,023.93$ \\
\hline Family farm income (PLN) & $46,797.33$ & $21,135.00$ & $113,721.00$ & $28,032.23$ \\
\hline Family farm income (PLN ha $\left.{ }^{-1}\right)$ & 1442.53 & 849.00 & 2243.00 & 372.45 \\
\hline \multicolumn{5}{|c|}{ Milk } \\
\hline Utilized agricultural area (ha) & 19.13 & 12.90 & 22.50 & 2.96 \\
\hline Total livestock unit (LU) & 20.17 & 14.10 & 27.00, & 4.50 \\
\hline Total output (PLN) & $115,330.67$ & $60,928.00$ & $175,076.00$ & $30,940.41$ \\
\hline Total inputs (PLN) & $88,252.33$ & $42,916.00$ & $129,854.00$ & $30,940.41$ \\
\hline
\end{tabular}


Table A2. Cont.

\begin{tabular}{|c|c|c|c|c|}
\hline Specification & Average & Min. & Max. & SD \\
\hline Fertilizers (PLN) & 7914.53 & 3748.00 & $11,778.00$ & 3043.14 \\
\hline Energy (PLN) & 9342.87 & 4315.00 & $13,013.00$ & 3264.85 \\
\hline Total intermediate consumption (PLN) & $65,534.33$ & $31,653.00$ & $97,070.00$ & $22,908.43$ \\
\hline Total inputs $\left(\mathrm{PLN} \mathrm{ha}^{-1}\right)$ & 4468.67 & 2869.00 & 5771.00 & 1006.58 \\
\hline Land productivity (PLN ha ${ }^{-1}$ ) & 5873.73 & 4185.00 & 7832.00 & 1236.60 \\
\hline Farm net value added $\left(\mathrm{PLN} \cdot \mathrm{AWU}^{-1}\right)$ & $29,603.73$ & $12,874.00$ & $49,893.00$ & $11,186.76$ \\
\hline Family farm income (PLN) & $48,952.87$ & $20,069.00$ & $85,401.00$ & $19,971.13$ \\
\hline Family farm income (PLN ha $\left.{ }^{-1}\right)$ & 2480.40 & 1342.00 & 3917.00 & 714.25 \\
\hline \multicolumn{5}{|c|}{ Mixed } \\
\hline Utilized agricultural area (ha) & 16.83 & 14.80 & 19.90 & 1.32 \\
\hline Total livestock unit (LU) & 12.47 & 10.90 & 14.30 & 1.09 \\
\hline Total output (PLN) & $82,903.47$ & $63,110.00$ & $117,397.00$ & $17,700.99$ \\
\hline Total inputs (PLN) & $77,282.40$ & $50,150.00$ & $114,631.00$ & $20,966.41$ \\
\hline Fertilizers (PLN) & 7583.80 & 4612.00 & $11,363.00$ & 2310.94 \\
\hline Energy (PLN) & 7747.00 & 4724.00 & $12,142.00$ & 2085.39 \\
\hline Total intermediate consumption (PLN) & $57,296.93$ & $37,961.00$ & $85,167.00$ & $14,988.95$ \\
\hline Total inputs (PLN ha ${ }^{-1}$ ) & 4598.40 & 3254.00 & 6163.00 & 944.21 \\
\hline Land productivity (PLN ha ${ }^{-1}$ ) & 4890.93 & 3802.00 & 6312.00 & 734.48 \\
\hline Farm net value added (PLN.AWU $\left.{ }^{-1}\right)$ & $17,554.33$ & $10,344.00$ & $22,836.00$ & 4079.47 \\
\hline Family farm income (PLN) & $22,283.53$ & $14,696.00$ & $31,387.00$ & 5290.34 \\
\hline Family farm income (PLN ha $\left.{ }^{-1}\right)$ & 1325.73 & 969.00 & 1949.00 & 313.05 \\
\hline
\end{tabular}

Source: Own calculation based on FADN data [28].

Table A3. Eigenvalues and proportions of total variance in 15 years as explained by the first two principal components for original traits and correlation coefficients between these traits and the first three PCs on milk production farms.

\section{Rotated Component Matrix.}

\begin{tabular}{|c|c|c|}
\hline \multirow{2}{*}{ Indicators } & \multicolumn{2}{|c|}{ Component } \\
\hline & 1 & 2 \\
\hline$X_{1}-$ Number of farms & 0.845 & 0.450 \\
\hline $\mathrm{X}_{2}$-Utilized agricultural area (ha) & 0.912 & 0.360 \\
\hline $\mathrm{X}_{3}$-Total livestock (LU) & 0.717 & 0.688 \\
\hline $\mathrm{X}_{4}$-Total output (PLN) & 0.837 & 0.531 \\
\hline $\mathrm{X}_{5}$-Total inputs (PLN) & 0.864 & 0.493 \\
\hline $\mathrm{X}_{6}$-Fertilizers (PLN) & 0.828 & 0.538 \\
\hline $\mathrm{X}_{7}$-Energy (PLN) & 0.944 & 0.299 \\
\hline $\mathrm{X}_{8}$-Total intermediate consumption (PLN) & 0.866 & 0.491 \\
\hline $\mathrm{X}_{9}-$ Total inputs $\left(\mathrm{PLN} \mathrm{ha}^{-1}\right)$ & 0.824 & 0.530 \\
\hline 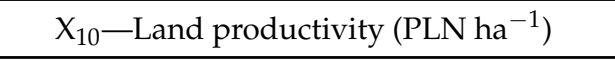 & 0.764 & 0.574 \\
\hline
\end{tabular}


Table A3. Cont.

\section{Rotated Component Matrix.}

\section{Indicators}

$\mathrm{X}_{11}$-Farm net value added (PLN AWU ${ }^{-1}$ )

$\mathrm{X}_{12}$-Family farm income (PLN)

$\mathrm{X}_{13}$-Family farm income (PLN ha ${ }^{-1}$ )

$\mathrm{Z}_{1}$-Dairy cattle $\mathrm{CH}_{4}$

$\mathrm{Z}_{2}$-Dairy cattle $\mathrm{N}_{2} \mathrm{O}$

$\mathrm{Z}_{3}$-Other cattle $\mathrm{CH}_{4}$

$\mathrm{Z}_{4}$-Other cattle $\mathrm{N}_{2} \mathrm{O}$

$\mathrm{Z}_{7}$-Total emissions $\mathrm{CH}_{4}\left(\mathrm{~kg} \mathrm{y}^{-1}\right)$

$\mathrm{Z}_{8}$-Emissions $\mathrm{CH}_{4}\left(\mathrm{~kg} \mathrm{ha}^{-1}\right)$

$\mathrm{Z}_{9}$-Total emissions $\mathrm{N}_{2} \mathrm{O}\left(\mathrm{kg} \mathrm{y}^{-1}\right)$

$\mathrm{Z}_{10}$-Emissions $\mathrm{N}_{2} \mathrm{O}\left(\mathrm{kg} \mathrm{ha}^{-1}\right)$

Component

12

$0.774 \quad 0.537$

0.7590 .566

$0.669 \quad 0.570$

$0.656 \quad 0.742$

$0.656 \quad 0.742$

$0.756 \quad 0.642$

$0.759 \quad 0.639$

$0.713 \quad 0.692$

$0.268 \quad 0.954$

$0.729 \quad 0.676$

$0.461 \quad 0.880$

Total variance explained-rotation sums of squared loadings

\begin{tabular}{ccc} 
Total & 12.052 & 8.035 \\
\% of variance & 57.388 & 38.264 \\
\hline Cumulative \% & 57.388 & 95.652
\end{tabular}

Extraction Method: Principal Component Analysis.

Rotation Method: Varimax with Kaiser Normalization.

Source: Own calculation based on FADN data [28].

Table A4. Eigenvalues and proportions of total variance in 15 years as explained by the first three principal components for original traits and correlation coefficients between these traits and the first three PCs on field crop farms.

\section{Rotated Component Matrix}

\begin{tabular}{|c|c|c|c|}
\hline \multirow{2}{*}{ Indicators } & \multicolumn{3}{|c|}{ Component } \\
\hline & 1 & 2 & 3 \\
\hline$X_{1}-$ Number of farms & -0.281 & -0.711 & 0.625 \\
\hline $\mathrm{X}_{2}$-Utilized agricultural area (ha) & -0.346 & 0.927 & -0.066 \\
\hline $\mathrm{X}_{3}$-Total livestock (LU) & 0.861 & -0.294 & -0.412 \\
\hline $\mathrm{X}_{4}$-Total output (PLN) & -0.315 & 0.933 & 0.155 \\
\hline $\mathrm{X}_{5}$-Total inputs (PLN) & -0.405 & 0.878 & 0.224 \\
\hline $\mathrm{X}_{6}-$ Mineral fertilizers (PLN) & -0.447 & 0.850 & 0.224 \\
\hline $\mathrm{X}_{7}$-Energy (PLN) & -0.329 & 0.921 & 0.148 \\
\hline $\mathrm{X}_{8}$-Total intermediate consumption (PLN) & -0.372 & 0.895 & 0.209 \\
\hline $\mathrm{X}_{9}-$ Total inputs $\left(\mathrm{PLN} \mathrm{ha}^{-1}\right)$ & -0.409 & 0.129 & 0.885 \\
\hline 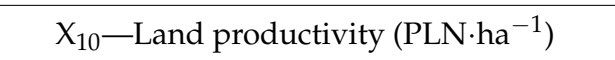 & -0.246 & 0.490 & 0.766 \\
\hline $\mathrm{X}_{11}-$ Farm net value added (PLN AWU ${ }^{-1}$ ) & -0.427 & 0.868 & 0.226 \\
\hline $\mathrm{X}_{12}$-Family farm income (PLN) & -0.297 & 0.939 & 0.112 \\
\hline $\mathrm{X}_{13}$-Family farm income (PLN.ha $\left.{ }^{-1}\right)$ & -0.297 & 0.760 & 0.445 \\
\hline
\end{tabular}


Table A4. Cont.

\begin{tabular}{|c|c|c|c|}
\hline \multicolumn{4}{|c|}{ Rotated Component Matrix } \\
\hline \multirow{2}{*}{ Indicators } & \multicolumn{3}{|c|}{ Component } \\
\hline & 1 & 2 & 3 \\
\hline $\mathrm{Z}_{1}$-Dairy cattle $\mathrm{CH}_{4}$ & 0.849 & -0.214 & -0.469 \\
\hline $\mathrm{Z}_{1}$-Dairy cattle $\mathrm{N}_{2} \mathrm{O}$ & 0.849 & -0.214 & -0.469 \\
\hline $\mathrm{Z}_{3}$-Other cattle $\mathrm{CH}_{4}$ & 0.915 & -0.308 & 0.029 \\
\hline $\mathrm{Z}_{4}$-Other cattle $\mathrm{N}_{2} \mathrm{O}$ & 0.915 & -0.308 & 0.029 \\
\hline $\mathrm{Z}_{5}$-Pigs $\mathrm{CH}_{4}$ & 0.728 & -0.364 & -0.518 \\
\hline $\mathrm{Z}_{6}$-Pigs $\mathrm{N}_{2} \mathrm{O}$ & 0.797 & -0.327 & -0.436 \\
\hline $\mathrm{Z}_{7}$-Total emissions $\mathrm{CH}_{4}\left(\mathrm{~kg} \cdot \mathrm{y}^{-1}\right)$ & 0.861 & -0.395 & -0.251 \\
\hline $\mathrm{Z}_{8}$-Emissions $\mathrm{CH}_{4}\left(\mathrm{~kg} \cdot \mathrm{ha}^{-1}\right)$ & 0.850 & -0.472 & -0.214 \\
\hline $\mathrm{Z}_{9}$-Total emissions $\mathrm{N}_{2} \mathrm{O}\left(\mathrm{kg} \cdot \mathrm{y}^{-1}\right)$ & 0.864 & -0.345 & -0.359 \\
\hline $\mathrm{Z}_{10}$-Emissions $\mathrm{N}_{2} \mathrm{O}\left(\mathrm{kg} \mathrm{ha}^{-1}\right)$ & 0.866 & -0.408 & -0.270 \\
\hline \multicolumn{4}{|c|}{ Total variance explained-rotation sums of squared loadings } \\
\hline Total & 9.473 & 9.117 & 3.597 \\
\hline$\%$ of variance & 41.188 & 39.641 & 15.638 \\
\hline Cumulative \% & 41.188 & 80.829 & 96.466 \\
\hline
\end{tabular}

Extraction Method: Principal Component Analysis.

Rotation Method: Varimax with Kaiser Normalization.

Source: Own calculation based on FADN data [28].

Table A5. Eigenvalues and proportions of total variance in 15 years as explained by the first four principal components for original traits and correlation coefficients between these traits and the first four PCs on mixed production farms.

\begin{tabular}{|c|c|c|c|c|}
\hline \multicolumn{5}{|c|}{ Rotated Component Matrix } \\
\hline \multirow{2}{*}{ Indicators } & \multicolumn{4}{|c|}{ Component } \\
\hline & 1 & 2 & 3 & 4 \\
\hline$X_{1}-$ Number of farms & -0.566 & 0.626 & -0.235 & -0.385 \\
\hline $\mathrm{X}_{2}$-Utilized agricultural area (ha) & 0.887 & -0.007 & -0.031 & 0.367 \\
\hline $\mathrm{X}_{3}$-Total livestock (LU) & 0.554 & 0.573 & -0.403 & 0.413 \\
\hline $\mathrm{X}_{4}$-Total output (PLN) & 0.959 & -0.048 & 0.265 & 0.047 \\
\hline $\mathrm{X}_{5}$-Total inputs (PLN) & 0.976 & -0.123 & 0.102 & 0.108 \\
\hline $\mathrm{X}_{6}$-Fertilizers (PLN) & 0.962 & -0.197 & 0.078 & 0.076 \\
\hline $\mathrm{X}_{7}$-Energy (PLN) & 0.906 & -0.047 & 0.348 & 0.000 \\
\hline $\mathrm{X}_{8}$-Total intermediate consumption (PLN) & 0.975 & -0.103 & 0.130 & 0.089 \\
\hline $\mathrm{X}_{9}-$ Total inputs $\left(\mathrm{PLN} \mathrm{ha}^{-1}\right)$ & 0.895 & -0.227 & 0.290 & -0.024 \\
\hline $\mathrm{X}_{10}-$ Land productivity $\left(\mathrm{PLN} \cdot \mathrm{ha}^{-1}\right)$ & 0.876 & -0.095 & 0.408 & -0.117 \\
\hline $\mathrm{X}_{11}$-Farm net value added (PLN AWU ${ }^{-1}$ ) & 0.648 & -0.268 & 0.662 & 0.212 \\
\hline $\mathrm{X}_{12}$-Family farm income (PLN) & 0.270 & -0.246 & 0.908 & 0.081 \\
\hline $\mathrm{X}_{13}$-Family farm income (PLN.ha $\left.{ }^{-1}\right)$ & -0.011 & -0.265 & 0.946 & -0.018 \\
\hline
\end{tabular}


Table A5. Cont.

\begin{tabular}{|c|c|c|c|c|}
\hline \multicolumn{5}{|c|}{ Rotated Component Matrix } \\
\hline \multirow{2}{*}{ Indicators } & \multicolumn{4}{|c|}{ Component } \\
\hline & 1 & 2 & 3 & 4 \\
\hline $\mathrm{Z}_{1}$-Dairy cattle $\mathrm{CH}_{4}$ & -0.481 & 0.778 & -0.293 & -0.133 \\
\hline $\mathrm{Z}_{2}$-Dairy cattle $\mathrm{N}_{2} \mathrm{O}$ & -0.481 & 0.778 & -0.293 & -0.133 \\
\hline $\mathrm{Z}_{3}$-Other cattle $\mathrm{CH}_{4}$ & 0.859 & -0.328 & -0.130 & 0.347 \\
\hline $\mathrm{Z}_{4}$-Other cattle $\mathrm{N}_{2} \mathrm{O}$ & 0.859 & -0.328 & -0.130 & 0.347 \\
\hline $\mathrm{Z}_{5}$-Pigs $\mathrm{CH}_{4}$ & -0.025 & 0.969 & -0.049 & 0.141 \\
\hline $\mathrm{Z}_{6}$-Pigs $\mathrm{N}_{2} \mathrm{O}$ & -0.021 & 0.963 & -0.053 & 0.142 \\
\hline $\mathrm{Z}_{7}$-Total emissions $\mathrm{CH}_{4}\left(\mathrm{~kg} \mathrm{y}^{-1}\right)$ & 0.810 & 0.169 & -0.360 & 0.382 \\
\hline $\mathrm{Z}_{8}$-Emissions $\mathrm{CH}_{4}\left(\mathrm{~kg} \mathrm{ha}^{-1}\right)$ & 0.174 & 0.178 & 0.121 & 0.845 \\
\hline $\mathrm{Z}_{9}$-Total emissions $\mathrm{N}_{2} \mathrm{O}\left(\mathrm{kg} \cdot \mathrm{y}^{-1}\right)$ & 0.750 & 0.436 & -0.249 & 0.412 \\
\hline $\mathrm{Z}_{10}$-Emissions $\mathrm{N}_{2} \mathrm{O}\left(\mathrm{kg} \cdot \mathrm{ha}^{-1}\right)$ & -0.014 & 0.769 & -0.413 & 0.153 \\
\hline \multicolumn{5}{|c|}{ Total variance explained-rotation sums of squared loadings } \\
\hline Total & 11.231 & 5.187 & 3.439 & 1.917 \\
\hline$\%$ of variance & 48.831 & 22.551 & 14.954 & 8.333 \\
\hline Cumulative \% & 48.831 & 71.382 & 86.336 & 94.669 \\
\hline
\end{tabular}

Extraction Method: Principal Component Analysis.

Rotation Method: Varimax with Kaiser Normalization.

Source: Own calculation based on FADN data [28]. 
Table A6. Correlation matrix of variables describing field crop farms.

\begin{tabular}{|c|c|c|c|c|c|c|c|c|c|c|c|c|c|c|c|c|c|c|c|c|c|c|c|}
\hline Variables & $x_{1}$ & $x_{2}$ & $x_{3}$ & $x_{4}$ & $x_{5}$ & $x_{6}$ & $x_{7}$ & $\mathrm{x}_{8}$ & $x_{9}$ & $x_{10}$ & $x_{11}$ & $x_{12}$ & $x_{13}$ & $\mathrm{z}_{1}$ & $z_{2}$ & $z_{3}$ & $\mathrm{z}_{4}$ & $z_{5}$ & $z_{6}$ & $\mathrm{z}_{7}$ & $\mathrm{z}_{8}$ & $z_{9}$ & $z_{10}$ \\
\hline$x_{1 .}$ & 1.000 & -0.598 & -0.293 & -0.470 & -0.364 & -0.338 & -0.462 & -0.397 & 0.570 & 0.186 & -0.351 & -0.508 & -0.191 & -0.375 & -0.375 & -0.015 & -0.015 & -0.269 & -0.261 & -0.115 & -0.038 & -0.226 & -0.122 \\
\hline$x_{2}$ & -0.598 & 1.000 & -0.544 & 0.964 & 0.949 & 0.931 & 0.960 & 0.951 & 0.203 & 0.456 & 0.935 & 0.965 & 0.752 & -0.459 & -0.458 & -0.574 & -0.574 & -0.579 & -0.577 & -0.652 & -0.717 & -0.603 & -0.670 \\
\hline$x_{3}$ & -0.293 & -0.544 & 1.000 & -0.611 & -0.699 & -0.729 & -0.613 & -0.669 & -0.753 & -0.667 & -0.720 & -0.582 & -0.661 & 0.990 & 0.990 & 0.866 & 0.866 & 0.945 & 0.962 & 0.951 & 0.955 & 0.994 & 0.976 \\
\hline $\mathrm{x}_{4}$ & -0.470 & 0.964 & -0.611 & 1.000 & 0.984 & 0.972 & 0.987 & 0.987 & 0.385 & 0.659 & 0.978 & 0.988 & 0.861 & -0536 & -0.536 & -0.575 & -0.575 & -0.645 & -0.624 & -0.676 & -0.739 & -0.649 & -0.691 \\
\hline$x_{5}$ & -0.364 & 0.949 & -0.699 & 0.984 & 1.000 & 0.993 & 0.989 & 0.998 & 0.492 & 0.674 & 0.975 & 0.959 & 0.843 & -0.632 & -0.632 & -0.611 & -0.611 & -0.739 & -0.724 & -0.763 & -0.812 & -0.734 & -0.775 \\
\hline$x_{6}$ & -0.338 & 0.931 & -0.729 & 0.972 & 0.993 & 1.000 & 0.980 & 0.993 & 0.515 & 0.676 & 0.967 & 0.942 & 0.829 & -0.667 & -0.667 & -0.650 & -0.650 & -0.743 & -0.743 & -0.781 & -0.835 & -0.755 & -0.796 \\
\hline$x_{7}$ & -0.462 & 0.960 & -0.613 & 0.987 & 0.989 & 0.980 & 1.000 & 0.994 & 0.404 & 0.625 & 0.962 & 0.966 & 0.826 & -0.541 & -0.541 & -0.567 & -0.567 & -0.647 & -0.626 & -0.700 & -0.756 & -0.651 & -0.703 \\
\hline$x_{8}$ & -0.397 & 0.951 & -0.669 & 0.987 & 0.998 & 0.993 & 0.994 & 1.000 & 0.473 & 0.668 & 0.970 & 0.960 & 0.837 & -0.600 & -0.600 & -0.592 & -0.592 & -0.708 & -0.692 & -0.739 & -0.790 & -0.704 & -0.747 \\
\hline$x_{9}$ & 0.570 & 0.203 & -0.753 & 0.385 & 0.492 & 0.515 & 0.404 & 0.473 & 1.000 & 0.828 & 0.469 & 0.321 & 0.565 & -0.786 & -0.786 & -0.379 & -0.379 & -0.795 & -0.755 & -0.642 & -0.608 & -0.710 & -0.648 \\
\hline$x_{10}$ & 0.186 & 0.456 & -0.667 & 0.659 & 0.674 & 0.676 & 0.625 & 0.668 & 0.828 & 1.000 & 0.706 & 0.625 & 0.852 & -0.664 & -0.664 & -0.437 & -0.437 & -0.704 & -0.638 & -0.593 & -0.597 & -0.641 & -0.589 \\
\hline$x_{11}$ & -0.351 & 0.935 & -0.720 & 0.978 & 0.975 & 0.967 & 0.962 & 0.970 & 0.469 & 0.706 & 1.000 & 0.981 & 0.919 & -0.662 & -0.662 & -0.657 & -0.657 & -0.744 & -0.719 & -0.751 & -0.814 & -0.753 & -0.785 \\
\hline$x_{12}$ & -0.508 & 0.965 & -0.582 & 0.988 & 0.959 & 0.942 & 0.966 & 0.960 & 0.321 & 0.625 & 0.981 & 1.000 & 0.886 & -0.512 & -0.512 & -0.565 & -0.565 & -0.619 & -0.587 & -0.637 & -0.711 & -0.625 & -0.669 \\
\hline$x_{13}$ & -0.191 & 0.752 & -0.661 & 0.861 & 0.843 & 0.829 & 0.826 & 0.837 & 0.565 & 0.852 & 0.919 & 0.886 & 1.000 & -0.639 & -0.639 & -0.547 & -0.547 & -0.701 & -0.629 & -0.643 & -0.695 & -0.676 & -0.676 \\
\hline$z_{1}$ & -0.375 & -0.459 & 0.990 & -0.536 & -0.632 & -0.667 & -0.541 & -0.600 & -0.786 & -0.664 & -0.662 & -0.512 & -0.639 & 1.000 & 1.000 & 0.826 & 0.826 & 0.929 & 0.951 & 0.917 & 0.920 & 0.975 & 0.951 \\
\hline$z_{2}$ & -0.375 & -0.458 & 0.990 & -0.536 & -0.632 & -0.667 & -0.541 & -0.600 & -0.786 & -0.664 & -0.662 & -0.512 & -0.639 & 1.000 & 1.000 & 0.826 & 0.826 & 0.929 & 0.951 & 0.917 & 0.920 & 0.975 & 0.951 \\
\hline$z_{3}$ & -0.015 & -0.574 & 0.866 & -0.575 & -0.611 & -0.650 & -0.567 & -0.592 & -0.379 & -0.437 & -0.657 & -0.565 & -0.547 & 0.826 & 0.826 & 1.000 & 1.000 & 0.719 & 0.766 & 0.890 & 0.910 & 0.873 & 0.885 \\
\hline$z_{4}$ & -0.015 & -0.574 & 0.866 & -0.575 & -0.611 & -0.650 & -0.567 & -0.592 & -0.379 & -0.437 & -0.657 & -0.565 & -0.547 & 0.826 & 0.826 & 1.000 & 1.000 & 0.719 & 0.766 & 0.890 & 0.910 & 0.873 & 0.885 \\
\hline$z_{5}$ & -0.269 & -0.579 & 0.945 & -0.645 & -0.739 & -0.743 & -0.647 & -0.708 & -0.795 & -0.704 & -0.744 & -0.619 & -0.701 & 0.929 & 0.929 & 0.719 & 0.719 & 1.000 & 0.961 & 0.910 & 0.898 & 0.954 & 0.935 \\
\hline$z_{8}$ & -0.038 & -0.717 & 0.955 & -0.739 & -0.812 & -0.835 & -0.756 & -0.790 & -0.608 & -0.597 & -0.814 & -0.711 & -0.695 & 0.920 & 0.920 & 0.910 & 0.910 & 0.898 & 0.924 & 0.987 & 1.000 & 0.971 & 0.989 \\
\hline$z_{9}$ & -0.226 & -0.603 & 0.994 & -0.649 & -0.734 & -0.755 & -0.651 & -0.704 & -0.710 & -0.641 & -0.753 & -0.625 & -0.676 & 0.975 & 0.975 & 0.873 & 0.873 & 0.954 & 0.968 & 0.967 & 0.971 & 1.000 & 0.991 \\
\hline $\mathrm{z}_{10}$ & -0.122 & -0.670 & 0.976 & -0.691 & -0.775 & -0.796 & -0.703 & -0.747 & -0.648 & -0.589 & -0.785 & -0.669 & -0.676 & 0.951 & 0.951 & 0.885 & 0.885 & 0.935 & 0.957 & 0.979 & 0.989 & 0.991 & 1.000 \\
\hline
\end{tabular}


Table A7. Correlation matrix of variables describing milk production farms.

\begin{tabular}{|c|c|c|c|c|c|c|c|c|c|c|c|c|c|c|c|c|c|c|c|c|c|}
\hline Variables & $X_{1}$ & $X_{2}$ & $X_{3}$ & $X_{4}$ & $X_{5}$ & $X_{6}$ & $X_{7}$ & $X_{8}$ & $X_{9}$ & $X_{10}$ & $X_{11}$ & $X_{12}$ & $X_{13}$ & $\mathrm{Z}_{1}$ & $\mathrm{Z}_{2}$ & $\mathrm{Z}_{3}$ & $\mathrm{Z}_{4}$ & $\mathrm{Z}_{7}$ & $\mathrm{Z}_{8}$ & $Z_{9}$ & $Z_{10}$ \\
\hline$X_{1}$ & 1.000 & 0.942 & 0.929 & 0.921 & 0.964 & 0.964 & 0.952 & 0.958 & 0.947 & 0.866 & 0.830 & 0.830 & 0.731 & 0.880 & 0.880 & 0.953 & 0.954 & 0.923 & 0.675 & 0.934 & 0.811 \\
\hline$x_{2}$ & 0.942 & 1.000 & 0.922 & 0.934 & 0.971 & 0.953 & 0.957 & 0.968 & 0.931 & 0.850 & 0.872 & 0.867 & 0.766 & 0.889 & 0.889 & 0.940 & 0.941 & 0.921 & 0.573 & 0.928 & 0.733 \\
\hline$X_{4}$ & 0.921 & 0.934 & 0.951 & 1.000 & 0.975 & 0.963 & 0.946 & 0.979 & 0.966 & 0.981 & 0.970 & 0.972 & 0.918 & 0.934 & 0.934 & 0.958 & 0.959 & 0.951 & 0.731 & 0.955 & 0.847 \\
\hline$X_{5}$ & 0.964 & 0.971 & 0.963 & 0.975 & 1.000 & 0.994 & 0.971 & 0.999 & 0.990 & 0.927 & 0.903 & 0.905 & 0.814 & 0.934 & 0.934 & 0.977 & 0.978 & 0.962 & 0.709 & 0.968 & 0.841 \\
\hline$x_{6}$ & 0.964 & 0.953 & 0.969 & 0.963 & 0.994 & 1.000 & 0.953 & 0.993 & 0.991 & 0.918 & 0.885 & 0.890 & 0.800 & 0.944 & 0.944 & 0.981 & 0.981 & 0.968 & 0.746 & 0.973 & 0.867 \\
\hline$x_{7}$ & 0.952 & 0.957 & 0.880 & 0.946 & 0.971 & 0.953 & 1.000 & 0.973 & 0.957 & 0.898 & 0.865 & 0.862 & 0.771 & 0.833 & 0.833 & 0.907 & 0.909 & 0.877 & 0.555 & 0.888 & 0.712 \\
\hline$x_{8}$ & 0.958 & 0.968 & 0.961 & 0.979 & 0.999 & 0.993 & 0.973 & 1.000 & 0.991 & 0.935 & 0.908 & 0.911 & 0.824 & 0.934 & 0.933 & 0.973 & 0.974 & 0.959 & 0.708 & 0.965 & 0.838 \\
\hline$X_{9}$ & 0.947 & 0.931 & 0.951 & 0.966 & 0.990 & 0.991 & 0.957 & 0.991 & 1.000 & 0.938 & 0.882 & 0.888 & 0.804 & 0.926 & 0.926 & 0.963 & 0.964 & 0.950 & 0.748 & 0.956 & 0.863 \\
\hline$X_{10}$ & 0.866 & 0.850 & 0.909 & 0.981 & 0.927 & 0.918 & 0.898 & 0.935 & 0.938 & 1.000 & 0.963 & 0.969 & 0.943 & 0.898 & 0.898 & 0.912 & 0.913 & 0.910 & 0.764 & 0.912 & 0.853 \\
\hline$X_{11}$ & 0.830 & 0.872 & 0.901 & 0.970 & 0.903 & 0.885 & 0.865 & 0.908 & 0.882 & 0.963 & 1.000 & 0.998 & 0.979 & 0.896 & 0.896 & 0.900 & 0.901 & 0.902 & 0.700 & 0.903 & 0.802 \\
\hline$x_{12}$ & 0.830 & 0.867 & 0.910 & 0.972 & 0.905 & 0.890 & 0.862 & 0.911 & 0.888 & 0.969 & 0.998 & 1.000 & 0.981 & 0.908 & 0.908 & 0.906 & 0.907 & 0.911 & 0.725 & 0.911 & 0.821 \\
\hline$x_{13}$ & 0.731 & 0.766 & 0.833 & 0.918 & 0.814 & 0.800 & 0.771 & 0.824 & 0.804 & 0.943 & 0.979 & 0.981 & 1.000 & 0.841 & 0.842 & 0.823 & 0.824 & 0.836 & 0.700 & 0.834 & 0.774 \\
\hline $\mathrm{Z}_{2}$ & 0.880 & 0.889 & 0.993 & 0.934 & 0.934 & 0.944 & 0.833 & 0.933 & 0.926 & 0.898 & 0.896 & 0.908 & 0.842 & 1.000 & 1.000 & 0.981 & 0.980 & 0.994 & 0.872 & 0.991 & 0.949 \\
\hline $\mathrm{Z}_{3}$ & 0.953 & 0.940 & 0.997 & 0.958 & 0.977 & 0.981 & 0.907 & 0.973 & 0.963 & 0.912 & 0.900 & 0.906 & 0.823 & 0.981 & 0.981 & 1.000 & 1.000 & 0.996 & 0.815 & 0.998 & 0.920 \\
\hline $\mathrm{Z}_{4}$ & 0.954 & 0.941 & 0.997 & 0.959 & 0.978 & 0.981 & 0.909 & 0.974 & 0.964 & 0.913 & 0.901 & 0.907 & 0.824 & 0.980 & 0.980 & 1.000 & 1.000 & 0.995 & 0.813 & 0.998 & 0.918 \\
\hline$Z_{7}$ & 0.923 & 0.921 & 1.000 & 0.951 & 0.962 & 0.968 & 0.877 & 0.959 & 0.950 & 0.910 & 0.902 & 0.911 & 0.836 & 0.995 & 0.994 & 0.996 & 0.995 & 1.000 & 0.846 & 1.000 & 0.938 \\
\hline $\mathrm{Z}_{8}$ & 0.675 & 0.573 & 0.844 & 0.731 & 0.709 & 0.746 & 0.555 & 0.708 & 0.748 & 0.764 & 0.700 & 0.725 & 0.700 & 0.872 & 0.872 & 0.815 & 0.813 & 0.846 & 1.000 & 0.836 & 0.977 \\
\hline $\mathrm{Z}_{9}$ & 0.934 & 0.928 & 1.000 & 0.955 & 0.968 & 0.973 & 0.888 & 0.965 & 0.956 & 0.912 & 0.903 & 0.911 & 0.834 & 0.991 & 0.991 & 0.998 & 0.998 & 1.000 & 0.836 & 1.000 & 0.932 \\
\hline$Z_{10}$ & 0.811 & 0.733 & 0.937 & 0.847 & 0.841 & 0.867 & 0.712 & 0.838 & 0.863 & 0.853 & 0.802 & 0.821 & 0.774 & 0.949 & 0.949 & 0.920 & 0.918 & 0.938 & 0.977 & 0.932 & 1.000 \\
\hline
\end{tabular}


Table A8. Correlation matrix of variables describing mixed production farms.

\begin{tabular}{|c|c|c|c|c|c|c|c|c|c|c|c|c|c|c|c|c|c|c|c|c|c|c|c|}
\hline Variables & $x_{1}$ & $x_{2}$ & $x_{3}$ & $x_{4}$ & $x_{5}$ & $x_{6}$ & $x_{7}$ & $x_{8}$ & $x_{9}$ & $x_{10}$ & $x_{11}$ & $x_{12}$ & $x_{13}$ & $\mathrm{z}_{1}$ & $\mathrm{z}_{2}$ & $\mathrm{z}_{3}$ & $z_{4}$ & $z_{5}$ & $z_{6}$ & $\mathrm{z}_{7}$ & $\mathrm{z}_{8}$ & $z_{9}$ & $z_{10}$ \\
\hline$x_{1}$ & 1.000 & -0.666 & -0.054 & -0.645 & -0.675 & -0.702 & -0.596 & -0.661 & -0.675 & -0.581 & -0.784 & -0.584 & -0.398 & 0.882 & 0.882 & -0.804 & -0.804 & 0.557 & 0.546 & -0.428 & -0.235 & -0.274 & 0.521 \\
\hline$x_{2}$ & -0.666 & 1.000 & 0.667 & 0.853 & 0.904 & 0.886 & 0.827 & 0.897 & 0.751 & 0.671 & 0.630 & 0.247 & -0.061 & -0.454 & -0.454 & 0.879 & 0.879 & 0.046 & 0.055 & 0.862 & 0.431 & 0.822 & -0.059 \\
\hline$x_{3}$ & -0.054 & 0.667 & 1.000 & 0.414 & 0.462 & 0.400 & 0.316 & 0.456 & 0.218 & 0.203 & 0.046 & -0.297 & -0.524 & 0.257 & 0.257 & 0.494 & 0.494 & 0.614 & 0.616 & 0.872 & 0.436 & 0.949 & 0.666 \\
\hline $\mathrm{x}_{4}$ & -0.645 & 0.853 & 0.414 & 1.000 & 0.975 & 0.956 & 0.963 & 0.982 & 0.942 & 0.958 & 0.820 & 0.514 & 0.253 & -0.576 & -0.576 & 0.822 & 0.822 & -0.087 & -0.086 & 0.695 & 0.243 & 0.648 & -0.147 \\
\hline$x_{5}$ & -0.675 & 0.904 & 0.462 & 0.975 & 1.000 & 0.991 & 0.945 & 0.999 & 0.939 & 0.897 & 0.744 & 0.379 & 0.100 & -0.605 & -0.605 & 0.891 & 0.891 & -0.135 & -0.133 & 0.762 & 0.293 & 0.685 & -0.160 \\
\hline$x_{6}$ & -0.702 & 0.886 & 0.400 & 0.956 & 0.991 & 1.000 & 0.935 & 0.987 & 0.938 & 0.884 & 0.722 & 0.360 & 0.088 & -0.661 & -0.661 & 0.890 & 0.890 & -0.195 & -0.189 & 0.719 & 0.254 & 0.634 & -0.218 \\
\hline$x_{7}$ & -0.596 & 0.827 & 0.316 & 0.963 & 0.945 & 0.935 & 1.000 & 0.955 & 0.926 & 0.923 & 0.804 & 0.542 & 0.292 & -0.562 & -0.562 & 0.719 & 0.719 & -0.078 & -0.075 & 0.572 & 0.261 & 0.549 & -0.285 \\
\hline $\mathrm{x}_{8}$ & -0.661 & 0.897 & 0.456 & 0.982 & 0.999 & 0.987 & 0.955 & 1.000 & 0.941 & 0.910 & 0.752 & 0.397 & 0.121 & -0.588 & -0.588 & 0.872 & 0.872 & -0.124 & -0.122 & 0.750 & 0.290 & 0.677 & -0.163 \\
\hline$x_{9}$ & -0.675 & 0.751 & 0.218 & 0.942 & 0.939 & 0.938 & 0.926 & 0.941 & 1.000 & 0.940 & 0.807 & 0.532 & 0.309 & -0.694 & -0.694 & 0.786 & 0.786 & -0.265 & -0.262 & 0.555 & 0.198 & 0.474 & -0.305 \\
\hline$x_{10}$ & -0.581 & 0.671 & 0.203 & 0.958 & 0.897 & 0.884 & 0.923 & 0.910 & 0.940 & 1.000 & 0.837 & 0.614 & 0.411 & -0.602 & -0.602 & 0.698 & 0.698 & -0.172 & -0.175 & 0.508 & 0.123 & 0.460 & -0.206 \\
\hline$x_{11}$ & -0.784 & 0.630 & 0.046 & 0.820 & 0.744 & 0.722 & 0.804 & 0.752 & 0.807 & 0.837 & 1.000 & 0.886 & 0.713 & -0.735 & -0.735 & 0.649 & 0.649 & $\begin{array}{l}-0.289 \\
\end{array}$ & -0.289 & 0.348 & 0.272 & 0.306 & -0.423 \\
\hline$x_{12}$ & -0.584 & 0.247 & -0.297 & 0.514 & 0.379 & 0.360 & 0.542 & 0.397 & 0.532 & 0.614 & 0.886 & 1.000 & 0.951 & $\begin{array}{l}-0.587 \\
\end{array}$ & -0.587 & 0.242 & 0.242 & -0.287 & -0.287 & -0.088 & 0.106 & -0.079 & -0.525 \\
\hline$x_{13}$ & -0.398 & -0.061 & $\begin{array}{l}-0.524 \\
\end{array}$ & 0.253 & 0.100 & 0.088 & 0.292 & 0.121 & 0.309 & 0.411 & 0713 & 0.951 & 1.000 & -0.471 & -0.471 & -0.028 & -0.028 & -0.319 & -0.322 & -0.370 & -0.014 & -0.349 & -0.537 \\
\hline$z_{1}$ & 0.882 & -0.454 & 0.257 & -0.576 & -0.605 & -0.661 & -0.562 & -0.588 & -0.694 & -0.602 & -0.735 & $\begin{array}{l}-0.587 \\
\end{array}$ & -0.471 & 1.000 & 1.000 & -0.682 & -0.682 & 0.727 & 0.718 & -0.176 & -0.074 & -0.013 & 0.659 \\
\hline$z_{2}$ & 0.882 & -0.454 & 0.257 & -0.576 & -0.605 & -0.661 & -0.562 & -0.588 & -0.694 & -0.602 & -0.735 & $\begin{array}{l}-0.587 \\
\end{array}$ & -0.471 & 1.000 & 1.000 & -0.682 & -0.682 & 0.727 & 0.718 & -0.176 & $\begin{array}{l}-0.074 \\
\end{array}$ & -0.013 & 0.659 \\
\hline$z_{3}$ & -0.804 & 0.879 & 0.494 & 0.822 & 0.891 & 0.890 & 0.719 & 0.872 & 0.786 & 0.698 & 0.649 & 0.242 & -0.028 & -0.682 & -0.682 & 1.000 & 1.000 & -0.291 & -0.285 & 0.838 & 0.326 & 0.690 & -0.108 \\
\hline$z_{4}$ & -0.804 & 0.879 & 0.494 & 0.822 & 0.891 & 0.890 & 0.719 & 0.872 & 0.786 & 0.698 & 0.649 & 0.242 & -0.028 & -0.682 & -0.682 & 1.000 & 1.000 & -0.291 & -0.285 & 0.838 & 0.326 & 0.690 & -0.108 \\
\hline$z_{5}$ & 0.557 & 0.046 & 0.614 & -0.087 & -0.135 & -0.195 & -0.078 & -0.124 & -0.265 & -0.172 & -0.289 & -0.287 & -0.319 & 0.727 & 0.727 & -0.291 & -0.291 & 1.000 & 0.999 & 0.188 & 0.259 & 0.480 & 0.768 \\
\hline$z_{6}$ & 0.546 & 0.055 & 0.616 & -0.086 & $\begin{array}{c}-0.133 \\
\end{array}$ & -0.189 & -0.075 & -0.122 & -0.262 & -0.175 & -0.289 & $\begin{array}{l}-0.287 \\
\end{array}$ & -0.322 & 0.718 & 0.718 & -0.285 & -0.285 & 0.999 & 1.000 & 0.191 & 0.251 & 0.484 & 0.761 \\
\hline$z_{8}$ & -0.235 & 0.431 & 0.436 & 0.243 & 0.293 & 0.254 & 0.261 & 0.290 & 0.198 & 0.123 & 0.272 & 0.106 & -0.014 & -0.074 & -0.074 & 0.326 & 0.326 & 0.259 & 0.251 & 0.405 & 1.000 & 0.473 & 0.150 \\
\hline $\mathrm{z}_{9}$ & -0.274 & 0.822 & 0.949 & 0.648 & 0.685 & 0.634 & 0.549 & 0.677 & 0.474 & 0.460 & 0.306 & -0.079 & -0.349 & -0.013 & -0.013 & 0.690 & 0.690 & 0.480 & 0.484 & 0.941 & 0.473 & 1.000 & 0.519 \\
\hline$z_{10}$ & 0.521 & -0.059 & 0.666 & -0.147 & -0.160 & -0.218 & -0.285 & -0.163 & -0.305 & -0.206 & -0.423 & -0.525 & -0.537 & 0.659 & 0.659 & -0.108 & -0.108 & 0.768 & 0.761 & 0.359 & 0.150 & 0.519 & 1.000 \\
\hline
\end{tabular}

Source: Own calculation based on FADN data [28]. 


\section{References}

1. Raport 2020. Polska Na Drodze Zrównoważonego Rozwoju. GUS, Warszawa, Poland. 2020. Available online: https:/ /raportsdg. stat.gov.pl/2020/cel13.html (accessed on 15 January 2021).

2. Emisja Gazów Cieplarnianych. Wybrane Zagadnienia Dotyczace Emisji CO2 w Polsce. Opracowanie Tematyczne OT-683; Kancelaria Senatu: Warszawa, Poland, 2020. Available online: https://www.senat.gov.pl/gfx/senat/pl/senatopracowania/192/plik/ot-68 3.pdf (accessed on 15 January 2021).

3. Dziennik Ustaw. Protokół z Kioto do Ramowej Konwencji Narodów Zjednoczonych w Sprawie Zmian Klimatu Sporządzony w Kioto Dnia 11 Grudnia 1997 r. (Dz. U. 2005, nr 203, poz. 1683). Available online: http:/ /isap.sejm.gov.pl/isap.nsf/DocDetails xsp?id=wdu20052031684 (accessed on 15 January 2021).

4. Emmerling, C.; Krein, A.; Junk, J. Meta-Analysis of Strategies to Reduce $\mathrm{NH}_{3}$ Emissions from Slurries in European Agriculture and Consequences from Greenhouse Gas Emissions. Agronomy 2020, 10, 1633. [CrossRef]

5. Nowakowicz-Dębek, B.; Wlazło, Ł.; Szymula, A.; Ossowski, M.; Kasela, M.; Chmielowiec-Korzeniowska, A.; Bis-Wencel, H. Estimating Methane Emissions from a Dairy Farm Using a Computer Program. Atmosphere 2020, 11, 803. [CrossRef]

6. Tongwane, M.I.; Moeletsi, M.E. A review of greenhouse gas emissions from the agriculture sector in Africa. Agric. Syst. 2018, 166, 124-134. [CrossRef]

7. Wiśniewski, P. Ocena wielkości emisji gazów cieplarnianych ze źródeł rolniczych na poziomie lokalnym w Polsce. Rocz. Ochr. Sr. 2018, 20, 1811-1829.

8. Gradziuk, P.; Gradziuk, B. Gospodarka niskoemisyjna-nowe wyzwanie dla gmin wiejskich. Wieś I Rolnictwo 2016, 1, 105-126. [CrossRef]

9. Zdeb, M. Redukcja Emisji Metanu i Węglowodorów Aromatycznych ze Składowisk Odpadów w Biofiltrze-Badania Polowe. Rocz. Ochr. Srodowiska 2015, 17, 1053-1073. Available online: https://ros.edu.pl/images/roczniki/2015/063_ROS_V17_R2015.pdf (accessed on 13 March 2021).

10. Rokicki, T.; Koszela, G.; Ochnio, I.; Golonko, M.; Zak, A.; Szczepaniuk, E.K.; Szczepaniuk, H.; Perkowska, A. Greenhouse Gas Emissions by Agriculture in EU Countries. Rocz. Ochr. Srodowiska 2020, 22, 809-824. Available online: http://ros.edu.pl/index. php?option=com_content\&view=article\&id=862:057-ros-v22-r2020\&catid=62\&lang=pl\&Itemid=299 (accessed on 13 March 2021).

11. Kassenberg, A.; Świrkula, E. Polska Niskoemisyjna, Od Idei Do Działania; Instytut na rzecz Ekorozwoju: Warszawa, Poland, 2015.

12. Krajowy Raport Inwentaryzacyjny. Inwentaryzacja Gazów Cieplarnianych w Polsce dla lat 1988-2018; KOBiZE: Warszawa, Poland, 2020; Available online: https://www.kobize.pl/uploads/materialy/materialy_do_pobrania/krajowa_inwentaryzacja_emisji/ NIR_2020_raport_syntetyczny_PL.pdf (accessed on 17 January 2021).

13. Krupin, V. Redukcja Emisji Gazów Cieplarnianych z Sektora Polskiego Rolnictwa: Misja Wykonalna? In Go2'50 Klimat Społeczeństwo Gospodarka; IOŚ-PIB: Warsaw, Poland, 2020; Volume 1, pp. 74-79. Available online: https://kobize.pl/uploads/ materialy/materialy_do_pobrania/aktualnosci/2020/GO250/publikator_PL_finalna_web.pdf (accessed on 15 February 2021).

14. Rebolledo-Leiva, R.; Angulo-Meza, L.; Iriarte, A.; Gonzalez-Araya, M.C. Joint carbo footprint assessment and data envelopment analysis for the reduction of greenhouse gas emissions in agriculture production. Sci. Total Environ. 2017, 594, 346. [CrossRef]

15. Garnier, J.; Le Noe, J.; Marescaux, A.; Sanz-Cobena, A.; Lassaletta, L.; Silvestre, M.; Thieu, V.; Billen, G. Long-term changes in grennhouse gas emission from French agriculture and livestock (1852-2014): From traditional agriculture to conventional intensive systems. Sci. Total Environ. 2019, 660, 1486-1501. [CrossRef]

16. Sanz-Cobena, A.; Lassoletta, L.; Aguilera, E.; de Prado, A.; Garnier, J.; Billen, G.; Iglesias, A.; Sanchez, B.; Guardia, G.; Abalos, D. Strategies for greenhouse gas emissions mitigation in Mediterranean agriculture: A review. Agric. Ecosyst. Environ. 2017, 238, 5-24. [CrossRef]

17. Gao, J.; Hou, H.; Zhai, Y.; Woodward, A.; Vardoulakis, S.; Kovats, S.; Wilkinson, P.; Li, L.; Song, X.; Xu, L.; et al. Greenhouse gas emissions reduction in deifferent economic sectors: Mitigation measures, health co-benefits, knowledge gaps and policy implications. Environ. Pollut. 2018, 240, 683-698. [CrossRef] [PubMed]

18. Khan, M.T.; Ali, Q.; Ashfag, M. The nexus between greenhouse gas emission, electricity production, renewable energy and agriculture in Pakistan. Renew. Energy 2018, 118, 437-451. [CrossRef]

19. Zafeiriou, E.; Mallidis, I.; Galanopoulas, K.; Arabatzis, G. Greenhouse Gas Emissions and Economic Performance in EU Agriculture; AnEmpirical Study in a Non-Linear Framework. Sustainability 2018, 10, 3837. [CrossRef]

20. Kastratovic, R. Impact of foreign direct investment on greenhouse gas emissions in agriculture of developing countries. Aust. J. Agric. Resour. Econ. 2019, 63, 620-642. [CrossRef]

21. Wass, A.; Kobus, P.; Krupin, V.; Witajewski-Baltvilks, J.; Cygiel, M. Ocena Wptywu Polityki Klimatycznej Na Sector Polskich Gospodarstw Rolnych; Centrum Analiz Klimatyczno-Energetycznych: Warszawa, Poland, 2020.

22. Castoldi, N.; Bechini, L. Intergated sustainability assesment of cropping systems with agro-ecological and economic indicators in northern Italy. Eur. J. Agron. 2010, 32, 59-72. [CrossRef]

23. Belanger, V.; Vanasse, A.; Parent, D.; Allard, G.; Pellerin, D. Delta: An integrated indicato-based self-assessment tool for the evaluation of dairy farms sustainability in Quebec Canada. Agroecol. Sustain. Food Syst. 2015, 39, 1022-1046. [CrossRef] 
24. Escribano, A.J.; Gaspar, J.P.; Mesias, F.J.D.; Moreno, A.F.P.; Escribano, M. A sustainability assesment of organic and conventional beef cattle farms in agroforestry system: The case of the "dehesa" rangelands. ITEA Inf. Tec. Econ. Agrar. 2014, 110, 343-367. Available online: http:/ / bazy.pb.edu.pl:2101/full_record.do?product=UA\&search_mode=GeneralSearch\&qid=11\&SID=W2 Wfvl6B (accessed on 30 January 2021).

25. Paracchini, M.L.; Bulgheroni, C.; Borreani, G.; Tabacco, E.; Banterle, A.; Bertoni, D.; Rossi, G.; Parolo, G.; Origgi, R.; De Paola, C. A diagnostics system to assess sustainability at a farm level: The SOSTARE model. Agric. Syst. 2015, 133, 35-53. [CrossRef]

26. Koloszko-Chomentowska, Z.; Zukovskis, J.; Gargasas, A. Ecological and economic sustainability of Polish and Lithuanian agricultural holdings specializing in animal production. In Proceedings of the 8th International Scientific Conference Rural Development Bioeconomy Challenges, Aleksandras Stulginskis University, Kaunas, Lithuania, 23-24 November 2017; pp. 1103-1107. [CrossRef]

27. Prus, P. Sustainable farming production and its impact on the natural environment-case study based on a selected group of farms. In Proceedings of the International Scientific Conference Rural Development Bioeconomy Challenges, Kaunas, Lithuania, 23-24 November 2017; pp. 1280-1285. [CrossRef]

28. Polski FADN. Available online: https://fadn.pl/publikacje/wyniki-standardowe-2/wyniki-standardowe-srednie-wazone/ (accessed on 20 January 2021).

29. Wilk, W. Wykorzystanie Danych Statystycznych i Wyników Rachunkowości Rolnej do Oceny Wpływu Rolnictwa na Środowisko w Ujęciu Makro- i Mikroekonomicznym; Studia I Raporty IUNG-PIB; Instytut Uprawy Nawożenia i Gleboznawstwa-Państwowy Instytut Badawcz: Pulawy, Poland, 2007; Volume 4, pp. 59-67. [CrossRef]

30. Piekut, K.; Machnacki, M. Ocena ekologiczno-ekonomiczna gospodarstw rolnych na podstawie danych FADN. Woda-ŚrodowiskoObszary Wiejskie 2011, 11, 203-219.

31. Syp, A.; Osuch, D. Szacowanie Emisji Gazów Cieplarnianych na Podstawie Danych FADN; Studia i Raporty IUNG-PIB. 2017, Volume 52, pp. 69-82. Available online: http://www.iung.pl/sir/zeszyt52_6.pdf (accessed on 21 January 2021).

32. IPCC 2006. Guidelines for National Greenhouse Gas Inventories. The Institute for Global Environmental Strategies (IGES) for the IPCC. Available online: https://www.ipcc.ch/report/2006-ipcc-guidelines-for-national-greenhouse-gas-inventories/ (accessed on 20 January 2021).

33. KOBiZE Krajowy Raport Inwentaryzacyjny. Inwentaryzacja Gazów Cieplarnianych W Polsce Dla Lat 1988-2016; IOŚ-PIB: Warszawa, Poland, 2018; Available online: https://www.kobize.pl/uploads/materialy/materialy_do_pobrania/krajowa_inwentaryzacja_ emisji/NIR_2018_raport_syntetyczny_PL.pdf (accessed on 20 January 2021).

34. Ji, E.S.; Park, K.-H. Methane and nitrous oxide emissions from livestock agriculture in 16 local administrative districts of Korea. Asian-Australas. J. Anim. Sci. 2012, 25, 1768-1774. [CrossRef]

35. Yue, Q.; Xu, X.; Hiller, J.; Cheng, K.; Pan, G. Mitigating greenhouse gas emissions in agriculture: From farm production to food consumption. J. Clean. Prod. 2017, 149, 1011-1019. [CrossRef]

36. Wysocka-Czubaszek, A.; Czubaszek, R.; Roj-Rojewski, S.; Banaszuk, P. Methane and Nitrous Oxide Emissions from Agriculture on a Regional Scale. J. Ecol. Eng. 2018, 19, 206-217. [CrossRef]

37. Dick, J.; Smith, R.; Lilly, A.; Moxey, A.; Booth, J.; Campbell, C.; Coulter, D. Calculating Farm Scale Greenhouse Gas Emissions; University of Aberdeen, The Macaulay Institute, Carbon Plan, Pareto Consulting, SAOS Ltd.: Scotland, UK, 2008.

38. Fereniec, J. Ekonomika I Organizacja Rolnictwa; Key Text: Warszawa, Poland, 1999.

39. GUS. Rocznik Statystyczny Rolnictwa Z Lat 2007-2019; GUS: Warszawa, Poland, 2020.

40. Jasińska, E. Indywidualne Gospodarstwa Rolne W Świetle Danych Rachunkowych Z Lat 1952-2001; IERiGŻ-PIB: Warszawa, Poland, 2008.

41. Seber, W.G.A. Multivariate Observations; John Wiley \& Sons: New York, NY, USA, 1984.

42. Morrison, D. Wielowymiarowa Analiza Statystyczna; PWN: Warszawa, Poland, 1990.

43. Carlson, K.M.; Gerber, J.S.; Mueller, N.D.; Herrero, M.; MacDonald, G.K.; Brauman, K.A.; Havlik, P.; O'Connell, C.S.; Johnson, J.A.; Saatchi, S.; et al. Grenhouse Gas Emissions Intensity of Global Croplands. Nat. Clim. Chang. 2017, 7, 63-68. [CrossRef]

44. Poore, J.; Nemecek, T. Reducing food's environment al imacts through producers and consumer. Science 2018, 360, 987-992. [CrossRef]

45. Wu, H.; Huang, H.; Tang, J.; Chen, W.; He, Y. Net greenhouse gas emissions from agriculture in China: Estimation, spatial correlation and convergence. Sustainability 2019, 11, 4817. [CrossRef]

46. Jarosz, Z.; Faber, A. Analiza przestrzennego zróżnicowania emisji podtlenku azotu z gruntów ornych w Polsce. Studia i Raporty IUNG-PIB. 2017, Volume 52, pp. 57-68. Available online: http://iung.pl/images/wyd/pib/zesz52.pdf (accessed on 20 March 2021).

47. Casey, J.W.; Holden, N.M. Analysis of greenhouse gas emissions from the average Irish milk production system. Agric. Syst. 2015, 86, 97-114. [CrossRef]

48. Dimitrov, D.D.; Wang, J. Geographic Inventory Framework for estimating spatial pattern of methane and nitrous oxide emissions from agriculture in Alberta, Canada. Environ. Dev. 2019, 32, 100461. [CrossRef]

49. Ren, C.; Liu, S.; van Grinsven, H.; Reis, S.; Jin, S.; Liu, H.; Gu, B. The impact of farm size on agricultural sustainability. J. Clean. Prod. 2019, 220, 357-367. [CrossRef]

50. Blandford, D.; Gaasland, I.; Vardal, E. Extensification versus Intensification in Reducing Greenhouse Gas Emissionsin Agriculture: Insights from Norway. Eurochoices 2013, 12, 4-9. [CrossRef] 
51. Ariva, J.; Viira, A.H.; Poldaru, R.; Roots, J. Medium-run projections for greenhouse gas emissions: Arising from agriculture: The case of milk production in Estonia. Agric. Food Sci. 2015, 24, 300-312. [CrossRef]

52. Grainger, C.; Bauchemin, K.A. Can enteric methane emissions from ruminants be lowered without lowering their production? Anim. Feed. Sci. Technol. 2011, 167, 308-320. [CrossRef]

53. Hoglund-Isaksson, L.; Gomez-Sanabria, A.; Klimont, Z.; Rafaj, P.; Schopp, W. Technical potentials and costs for reducing global anthropogenic methane emissions in the 2050 timeframe-results from the GAINS model. Environ. Res. Commun. 2020, 2. [CrossRef]

54. Ocko, I.B.; Sun, T.; Shindell, D.; Oppenheimer, M.; Hristov, A.N.; Pacala, S.W.; Mauzerall, D.L.; Xu, Y.; Hamburg, S.P. Acting rapidly to deploy readily available methane mitigation measures by sector can immediately slow global warming. Environ. Res. Lett. 2021, 16, 054042. Available online: https://iopscience.iop.org/article/10.1088/1748-9326/abf9c8/pdf (accessed on 30 May 2021). [CrossRef]

55. Koloszko-Chomentowska, Z. Influence of the Common Agricultural Policy on the development of family agricultural farms in the Podlaskie Province. Econ. Reg. Stud. 2018, 11, 51-68. Available online: http://www.ers.edu.pl/OJS/index.php/erspl/article/ view/340/335 (accessed on 10 March 2021). [CrossRef]

56. Some, T.E.; Mbaye, A.A.; Barbier, B. Greenhouse Gas Emission Reduction in Agriculture: Trade-off ot Win-Win Situation for Small Farmers in the Sudanian Area of Burkina Faso? Afr. Dev. Rev. Rev. Afr. Dev. 2017, 29 (Suppl. 2), 163-178. [CrossRef] 